\title{
Articles
}

\section{Court Presidents: The Missing Piece in the Puzzle of Judicial Governance}

\author{
By Adam Blisa* \& David Kosař ${ }^{* *}$
}

\begin{abstract}
:
The aim of this paper is to provide a new comprehensive understanding of roles of court presidents in judicial governance in Europe. It argues that in order to better understand the role of court presidents in comparative perspective it is necessary to unpack their power into smaller components that can be analyzed separately. We define seven such components: judicial career, jurisprudential, administrative, financial, ambassadorial, and media power, and ancillary powers as a residual category. Subsequently, we zero in on 13 European jurisdictions and rate them according to the strength of their court presidents' powers. By doing so we are developing a Court President Power Index. Based on this Index we question the claim that Western court presidents are always weaker than their Eastern European counterparts and argue that powers of court presidents diverge both within Western Europe and within Eastern Europe, and hence it is difficult to draw the easy line along the West/East axis on this ground. Finally, we problematize our Court President Power Index and show that powers in the meaning of faculty do not necessarily translate into influence since various contingent circumstances (such as the length of court presidents' terms of office, information asymmetry, the structure of the judiciary, the existence of competing judicial self-governance bodies, the role of individuals, the proximity of court presidents to political leaders, the legal profession, legal culture, and the political environment) affect to what extent court presidents may exploit their powers in practice.
\end{abstract}

\footnotetext{
*Adam Blisa is a Researcher at the Judicial Studies Institute, Ph.D. Candidate at the Department of Constitutional Law and Political Science at the Faculty of Law of Masaryk University, and Law Clerk to a Judge at the Supreme Administrative Court of the Czech Republic. Email: adam.blisa@law.muni.cz.

** David Kosař is the Director of the Judicial Studies Institute (JUSTIN) at the Law Faculty of Masaryk University, Brno. Email: david.kosar@law.muni.cz. We are grateful to Alexandra Huneeus, Julio Ríos-Figueroa, Chris Hanretty, the participants of JUSTIN research meetings, contributors to this special issue, and to audiences in Mexico City, Oslo, Oxford and Toronto for helpful comments on earlier versions of this article. The research leading to this article has received funding from the European Research Council (ERC) under the European Union's Horizon 2020 research and innovation programme (grant no. 678375-JUDI-ARCH-ERC-2015-STG).
} 
When Viktor Orbán's regime ousted the sitting Chief Justice of the Hungarian Supreme Court, András Baka, ${ }^{1}$ who dared to criticize the judicial reforms adopted by Fidesz, many stakeholders were appalled. Most of them did not even notice that Orbán also got rid of the Supreme Court Vice-President (by statutory amendment) ${ }^{2}$ and many lower court presidents (by reducing the compulsory retirement age for judges). ${ }^{3} \mathrm{~A}$ few years later, the Law and Justice Government in Poland followed this script. Kaczyński gave his Minister of Justice Zbigniew Ziobro a six-month window, which allowed Ziobro to dismiss court presidents and appoint new ones without consultation. Ziobro fully exploited this "window of opportunity" to replace almost 150 court presidents and vice presidents. ${ }^{4}$ Law and Justice also reduced the compulsory retirement age for judges from 70 to 65 years, which "by accident" applied also to the Polish Supreme Court President, Małgorzata Gersdorf, who turned 65 in 2017 and whose constitutional term of office was supposed to end only in $2020 .^{5}$

However, this is just the tip of the iceberg. ${ }^{6}$ In fact, political leaders in the CEE region dismissed (or attempted to dismiss) not only András Baka and Małgorzata Gersdorf, but also Supreme Court Chief Justices in Croatia $^{7}$ and Czechia, ${ }^{8}$ and court presidents in Slovakia. ${ }^{9}$ Most recently, it was reported that the Bulgarian Chief Justice is under pressure

\footnotetext{
${ }^{1}$ See Attila Vincze, Dismissal of the President of the Hungarian Supreme Court: ECtHR Judgment Baka v. Hungary, 21 European Public LaW 445 (2015); and David Kosař \& Katarína Šipulová, The Strasbourg Court Meets Abusive Constitutionalism: Baka v. Hungary and the Rule of Law, 10 HAGUE JOURNAL ON THE RULE OF LAW 83 (2018).

2 See Erményi v Hungary, EUR. CT. H. R. (Judgment of 22 November 2016, app. no. 22254/14); and Kosař \& Šipulová, supra note 1.

${ }^{3}$ See Uladzislau Belavusau, On Age Discrimination and Beating Dead Dogs: Commission v. Hungary, 50 C.M.L.R. 1145 (2013); Tomás Gyulavári \& Nikolett Hős, Retirement of Hungarian Judges, Age Discrimination and Judicial Independence: A Tale of Two Courts. 42 IndUSTRIAL LAW JOURNAL 289 (2013); and Gábor Halmai, The early retirement age of the Hungarian judges, in EU LAW StORIES. CONTEXTUAL AND CRITICAL HISTORIES OF EUROPEAN JURISPRUDENCE 471-488 (Fernanda Nicola \& Bill Davis, eds., Cambridge University Press 2017).

${ }^{4}$ See Anna Śledzińska-Simon, The Rise and Fall of Judicial Self-Government in Poland: On Judicial Reform Reversing Democratic Transition, in this issue; and Adam Bodnar, Europe can save Poland from darkness, Politico (Apr. 9, 2018), https://www.politico.eu/article/poland-judiciary-rule-of-law-europe-must-intervene/.

${ }^{5}$ See Śledzińska-Simon, supra note 4; and Wojciech Sadurski, Polish Chief Justice of the Supreme Court Under Pressure: What Now? VERFBLOG (Jul. 5, 2018), https://verfassungsblog.de/polish-chief-justice-of-the-supremecourt-under-pressure-what-now/.

${ }^{6}$ Kosař \& Šipulová, supra note 1.

7 Alan Uzelac, Role and Status of Judges in Croatia, in RICHTERbILD UND ReCHTSReform IN MitTeleuropa (Paul Oberhammer ed., Manzsche Verlags 2001).

${ }^{8}$ Michal Bobek, The Administration of Courts in the Czech Republic - In Search of a Constitutional Balance, 16 EUROPEAN PUBLIC LAW 251 (2010).
} 
from the Chief Prosecutor. ${ }^{10}$ When it comes to lower court presidents, their discretionary dismissals also were ${ }^{11}$ or have been ${ }^{12}$ a common practice in the region. For instance, each Slovak minister of justice since 1998 who has remained in office for two or more years has replaced more than $25 \%$ of all court presidents. ${ }^{13}$ Three of them replaced more than $50 \%$ of court presidents, ${ }^{14}$ which is much more than Law and Justice in Poland within the last three years. A similar practice flourishes in Ukraine, where 'recalcitrant' court presidents have often faced reprisals, both before ${ }^{15}$ and after $^{16}$ the Euromaidan.

These controversial moves drew significant attention to the role of court presidents in CEE judiciaries. What powers do the CEE court presidents have if it is so important to the political leaders to install their own people in these positions? Put differently, there must be something special about their role within the court administration. Otherwise, political leaders would not care so much about them. Several scholars showed what broad powers some court presidents in CEE wield, ${ }^{17}$ which may in turn explain why the CEE political leaders pay so much attention to the selection of court presidents and are even willing to dismiss incumbent court presidents, despite heavy political costs on the domestic as well as international level. ${ }^{18}$

One may object that replacing incumbent court presidents by judges loyal to the new populist regime has little bearing on the greater scheme of things, especially in comparison

\footnotetext{
9 DAVId Kosař, PeriLS OF JUdicial Self-Government IN TRANSITIONAL SOCIETIES 279-80 (2016); and Report of the Special Rapporteur on the Independence of Judges and Lawyers on His Mission to the Slovak Republic (November 27-29, 2000), E/CN.4/2001/65/Add.3, paras. 27-33.

${ }^{10}$ Radosveta Vassileva, The Disheartening Speech by the President of Bulgaria's Supreme Court Which Nobody in Brussels Noticed, VerfBLOG (July 11, 2018), https://verfassungsblog.de/the-disheartening-speech-by-thepresident-of-bulgarias-supreme-court-which-nobody-in-brussels-noticed/.

${ }^{11}$ See David Kosař, Politics of Judicial Independence and Judicial Accountability in Czechia: Bargaining in the Shadow of the Law between Court Presidents and the Ministry of Justice, 13 EUROPEAN CONST. LAW R. 96 (2017).

${ }^{12}$ See Samuel Spáč and David Kosař, Court Presidents in Slovakia: From Transmission Belts to Transmission Belts?, (unpublished manuscript, on file with authors, 2018).

${ }^{13}$ Ibid.

${ }^{14}$ Ibid.

${ }^{15}$ See e.g. Denisov v Ukraine, EUR. CT. H. R. (Judgment of 25 September 2018, app. no. 76639/11) (concerning the president of the influential Kyiv Administrative Court of Appeal).

${ }^{16}$ Maria Popova, Ukraine's Judiciary after Euromaidan, (unpublished manuscript, on file with authors 2018).

${ }^{17}$ See e.g. Maria Popova, Politicized Justice in Emerging Democracies: A Study of Courts in Russia and Ukraine (2012); Lydia F. Müller, Judicial Administration in Transitional Eastern Countries, in JUDICIAL INDEPENDENCE IN TRANIITION 937 (Anja Seibert-Fohr ed., 2012); and Kosař, supra note 9, at 279-280.

${ }^{18}$ See the examples mentioned above.
} 
to attacks on constitutional courts, court-packing strategies, weakening judicial councils, and capturing the process of selection of judges. However, as shown above, populist political leaders in Hungary, Poland, and other CEE countries care about the control of court presidents. They care about court presidents, because they know that it is a powerful channel of politicization and taming of the judiciary. They might favor this channel also for other reasons - because it is less visible and more difficult to fight, because it allows for continual control of the judiciary (in contrast to single acts such as selection or promotion), or because loyal court presidents may serve as a valuable source of information for the political leaders about what is going on within the judiciary, which in turn helps them to suppress the potential revolt of judges from the outset. ${ }^{19}$ We should thus care as well. If we want to prevent (or at least slow down) the capture of the judiciary by populist leaders, we need to know what CEE court presidents do, who they are, what are their motivations, why CEE political leaders replace them, and what the potential channels of politicization of the judiciary via court presidents are.

However, the selection of court presidents has become increasingly controversial also in Western Europe. As early as in 1997, the Prince of Liechtenstein's refusal to reappoint sitting president Wille for yet another term as the President of the Liechtenstein Administrative Court due to Mr. Wille's public statements regarding the scope of the Prince's power caused an outcry that eventually ended up before the Grand Chamber of the European Court of Human Rights. ${ }^{20}$ Even in Norway, where judicial politics have rarely been discussed in public, the most recent appointment to the position of the Chief Justice drew severe criticism from the political opposition, scholars as well as the insiders. ${ }^{21}$

Beyond Europe, some of the stories regarding court presidents are even more dramatic. When the Pakistani President suspended the Chief Justice of Pakistan, Iftikhar Muhammad Chaudhry, in 2007, it caused a nationwide popular mass protest movement led by lawyers who eventually succeeded in getting Mr. Chaudhry reinstated to the office of Chief Justice. ${ }^{22}$ In contrast, in Peru ${ }^{23}$ and Indonesia, ${ }^{24}$ chief justices had to resign amid corruption

\footnotetext{
${ }^{19}$ See also notes $255-257$ below.

${ }^{20}$ Wille v. Liechtenstein, EUR. CT. H. R. (Judgment of the Grand Chamber of 28 October 1999, app. no. 28396/95).

${ }^{21}$ Anine Kierulf, Norway: New Chief Justice Appointed to the Supreme Court, I-CONNECT (March 1, 2016), http://www.iconnectblog.com/2016/03/norway-new-chief-justice/.

22 See llyas Khan, Judge row prompts Pakistan democracy questions, BBC NEWs (March 12, 2007), http://news.bbc.co.uk/2/hi/south_asia/6442829.stm; and Pakistan's top judge reinstated, BBC NEWS (July 20, 2007), http://news.bbc.co.uk/2/hi/south_asia/6907685.stm. For more details, see Shoaib A. Ghias, Miscarriage of Chief Justice: Judicial Power and the Legal Complex in Pakistan under Musharraf, 35 LAW \& SOCIAL INQUIRY 985 (2010).

${ }^{23}$ See Peru political turmoil: Supreme court president resigns over tapes scandal, BBC NEWS (July 19, 2018), https://www.bbc.com/news/world-latin-america-44892884.
} 
scandals. In all three countries, these events led to constitutional crises. Even established democracies are not spared such dramas, as the Tim Carmody affair attests. When Tim Carmody was appointed the Chief Justice of Queensland by Premier Campbell Newman in 2014, it tore the Australian legal profession apart and eventually evolved into Australia's greatest judicial crisis. ${ }^{25}$

The role of court presidents became more visible at international and supranational courts too. For instance, some actions of the President of the Court of Justice of the European Union, Vassilios Skouris, who presided over the CJEU from 2003 to 2015, became the subject of scholarly criticism. First, the manner of his involvement in the judicial reform of the CJEU and the subsequent lobbying for it raised serious concerns. ${ }^{26}$ Second, Skouris' actions within the Court of Justice itself caused a split between him and the President of the General Court, Marc Jaeger. ${ }^{27}$ No controversy on such a scale has reached the Strasbourg Court so far, but even within the Strasbourg community, everybody knows how important the ECtHR President is. For instance, both Luzius Wildhaber and Jean-Paul Costa acted as judicial diplomats, and the latter played a pivotal role in persuading Russia to ratify Protocol No. 14 to the European Convention on Human Rights. ${ }^{28}$ After the election of Sir Nicholas Bratza to the post of the ECtHR President, many insiders suggested that this move was motivated by the need to appease the increasingly critical Government of the United Kingdom. The growing role of new internal judicial self-governance bodies within the ECtHR, such as the Bureau, ${ }^{29}$ makes the selection of the ECtHR's president even more important.

Given this ample evidence of how important court presidents are in running the judiciaries, there is surprisingly little written on this topic. ${ }^{30}$ The aim of this article is to reduce this gap

\footnotetext{
${ }^{24}$ See, e.g., Joe Cochrane, Top Indonesian Judge Held in Corruption Case, THE NEW YoRK TIMES (October 3, 2013), https://www.nytimes.com/2013/10/04/world/asia/indonesias-top-judge-held-in-corruption-case.html; and Exhead of Indonesia's constitutional court jailed for life for graft, REUTERS (June 30, 2014), https://uk.reuters.com/article/uk-indonesia-corruption/ex-head-of-indonesias-constitutional-court-jailed-for-lifefor-graft-idUKKBNOF51Z420140630.

${ }^{25}$ See Rebecca Ananian-Welsh, Gabrielle Appleby \& Andrew Lynch, The Tim Carmody Affair: Australia's Greatest JUDICIAL CRISIS (2016).

${ }^{26}$ Christoph Krenn, Governing the European Court of Justice: Self-governance as a Model for Success, in this issue.

${ }^{27}$ See Duncan Robinson, The 1st rule of ECJ fight club...is about to be broken, FINANCIAL TIMES: BRUSSELS BLOG (April 27, 2015), http://blogs.ft.com/brusselsblog/2015/04/27/the-1st-rule-of-ecj-flight-club-is-about-to-be-broken.

${ }^{28}$ See Jennifer W. Reis, Protocol No. 14 ECHR and Russian No. 14: The Current State of Affairs, 22 HARVARD HUMAN RIGHTS JOURNAL 293 (2009).

${ }^{29}$ See Başak Çalı \& Stewart Cunningham, Judicial Self Government and the sui generis case of the European Court of Human Rights, in this issue.

${ }^{30}$ For more details, see Part A.
} 
and to provide a new comprehensive understanding of roles of court presidents in judicial governance in Europe. In order to do so, we identify powers of court presidents and then conduct a multiple-country comparison, which results in the Court Presidents Power Index. By doing so, we make the following contributions to the existing literature on court administration and judicial studies more generally. First, we provide the first comprehensive typology of powers of court presidents that is divorced from the peculiarities of a single jurisdiction and allows for a comparison within and across jurisdictions. Second, we challenge the conventional wisdom ${ }^{31}$ that there is a clear West/East division regarding the powers of court presidents in Europe. Third, our approach is also novel in that we study transnational courts and domestic courts together. We believe that both theoretically and empirically there is much to gain from comparisons between these two levels. Therefore, we zero in not only on domestic court presidents within Europe, but also on the role of presidents of the European Court of Human Rights and the Court of Justice of the European Union.

More specifically, we argue that in order to better understand the role of court presidents in comparative perspective it is necessary to unpack their power into smaller components that can be analyzed separately. We define seven such components: power over judicial careers, jurisprudential power, administrative power, financial power, ambassadorial power, media power, and the residual category of ancillary powers. Regarding the abovementioned West/East division, we argue that powers of court presidents diverge both within Western Europe and within Eastern Europe and thus it is difficult to draw a simple line along the West/East axis on this ground. When we add both supranational European courts to the picture, it becomes even clearer that there is no consensus in Europe regarding the role of court presidents.

This article proceeds as follows. Part A summarizes the state of the art and shows that we still know little about court presidents. Part B introduces a novel taxonomy of powers of court presidents. In doing so, it zeroes in on both the de iure and de facto powers and, given the scarcity of the relevant literature, uses examples not only from the European jurisdictions covered by this special issue, but from all over the world. Part $C$ then focuses on the selected European jurisdictions and rates them according to the strength of their court presidents' powers. This rating results in the Court Presidents Power Index. Subsequently, we identify five types of court presidents and revisit the view that there are sharp differences between the roles of court presidents in the West Europe on the one hand and the Eastern Europe on the other. Part D problematizes the Court Presidents Power Index and shows what contingent circumstances may affect to what extent court presidents can exploit their powers in practice. Part E concludes.

\footnotetext{
${ }^{31}$ See Part D of this article.
} 


\section{A. What do We Know about the Court Presidents?: Summarizing the State of the Art}

It is the most visible institutions, such as judicial councils or judicial appointment boards, that are the usual subject of judicial self-governance (JSG) studies. ${ }^{32}$ This is caused by the tendency to squeeze all forms of judicial self-governance into the existing models of court administration. However, there are also other JSG bodies. ${ }^{33}$ The court presidents are one of them. Apart from the Chief Justice of the Supreme Court of the United States, ${ }^{34}$ court presidents in other jurisdictions (and even court presidents of other federal and state courts in the United States) receive significantly less attention than judicial councils and, if they do, it is usually only in connection with other, bigger issues, such as judicial independence, rather than the main focus of the inquiry.

This is surprising, given the fact that historically, in many countries characterized by bureaucratic-type judiciaries, court presidents used to and often continue to play an important role. This is so especially in the CEE countries with the Austro-German heritage of administration of courts where court presidents are especially powerful and enjoy a peculiar status as both judges and administrators. ${ }^{35}$ Such position makes them significant players in so many areas that we could even say they influence not only judges' careers right from the beginning to the very end, be it in their selection and appointment,

${ }^{32}$ For a thorough introduction, see David Kosař, Beyond Judicial Councils: Forms, Rationales and Impact of Judicial Self-Government in Europe, in this issue.

${ }^{33}$ We define JSG body as a body with at least one judge whose primary function, entrenched in a legal norm, is to decide about issues regarding court administration and/or the career of a judge, and/or advise those who decide about such issues. See also Kosař, supra note 32.

${ }^{34}$ DAVID J. DANelSkI, A Supreme Court Justice IS Appointed (1964); Sandra L. Wood, Linda C. Keith, Drew N. Lanier \& Ayo Ogundele, Opinion Assignment and the Chief Justice, 81 SOCIAL SCIENCE QUARTERLY 798 (2000); Todd E. Pettys, Choosing a Chief Justice: Presidential Prerogative Or a Job for the Court?, 22 J. OF L. \& PoLITICS 231 (2006); Joel K. Goldstein, Leading the Court: Studies in Influence as Chief Justice, 40 STETSON LAW REVIEW 717 (2011); Drew N. Lanier, Acclimation Effects and the Chief Justice: The Influence of Tenure on the Decisional Behavior of the Court's Leader, 1888-2007, 39 American Politics ReSEARCH 682 (2011); DAVID J. DANELSKI \& ARTEMUS WARD, THe CHIEF JUstice: APPOINTMENT AND INFLUENCE (2016); Forrest Maltzman \& Paul J. Wahlbeck, May It Please the Chief? Opinion Assignments in the Rehnquist Court, 40 AmericAN Journal OF PolticAL SCIENCE 421 (1996); Forrest Maltzman \& Paul J. Wahlbeck, A Conditional Model of Opinion Assignment on the Supreme Court, 57 PolitiCAL RESEARCH QUARTERLY 551 (2004); Paul J. Wahlbeck, Strategy and Constraints on Supreme Court Opinion Assignment, 154 UNIVERSITY OF Pennsylvania Law Review 1729 (2006); G. Edward White, The Internal Powers of the Chief Justice: The NineteenthCentury Legacy, 154 University of Pennsylvania LAW ReVIeW 1463 (2006); Jeffrey R. Lax \& Charles M. Cameron, Bargaining and Opinion Assignment on the US Supreme Court, 23 JOURNAL OF LAW, ECONOMICS \& ORGANIZATION 276 (2007); see also the biographies of Chief Justices, e. g. KENNETH BERNARD UMBREIT, OUR ELEVEN CHIEF JUSTICES (1938); Abe Fortas, Chief Justice Warren: The Enigma of Leadership, 84 YALE L. J. 405 (1975); HERBERT A. JOHNSON, THE CHIEF

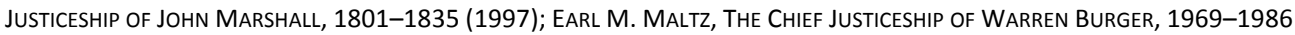
(2000); and R. KENT NeWMyer, The SUPREME COURT UNDER MARSHALL AND TANEY (2005).

${ }^{35}$ Bobek, supra note 8 , at 251, 252-254. 
evaluation, promotion and reassignment, ${ }^{36}$ and in holding them to account, ${ }^{37}$ but also their day-to-day work by creating work schedules ${ }^{38}$ and assigning cases, ${ }^{39}$ or controlling parts of salaries ${ }^{40}$ and discretionary perks. ${ }^{41}$

Looking into the powers of CEE countries' court presidents and the power relations between them and other branches of power, we see that they can take up the role of a principal JSG actor. ${ }^{42}$ Such vast power of court presidents is understandably not at all unproblematic as, coupled with a strong position in another JSG body such as a judicial council, it could lead to abuse and accountability perversions. ${ }^{43}$ The court presidents' importance is by no means limited to the CEE countries - influential court presidents exist also in Latin America, ${ }^{44}$ the United States ${ }^{45}$ or Asian countries. ${ }^{46}$ An extensive literature is

${ }^{36}$ A very rich source of information on court presidents not only in CEE countries, but also in some of the developed western democracies, are the national reports in JUDICIAL INDEPENDENCE IN TRANSITION (Anja Seibert-Fohr ed., 2012); especially by Adam Bodnar and Łukasz Bojarski on Poland at 667, by Zoltán Fleck on Hungary at 793, by Ramona Coman and Cristina Dallara on Romania at 835, by Olga Schwartz and Elga Sykiainen on Russia at 971.

37 Daniela Piana, Judicial Accountabilities in NeW Europe: From Rule of LaW to Quality of Justice 43-4 (2010); see also David Kosař, The Least Accountable Branch, 11 INT'L J. OF CONST. LAW 234 (2013) setting straight some claims that Daniela Piana makes in her book.

${ }^{38}$ Giuseppe Di Federico, Judicial Independence in Italy, in Seibert-Fohr, supra note 17, at 357, 378-379.

${ }^{39}$ Schwartz \& Sykiainen, supra note 36 , at 1019-1021.

${ }^{40}$ This was the case of Slovakia, see Kosař, supra note 9, at 279-280.

${ }^{41}$ Peter H. Solomon, Authoritarian legality and informal practices: Judges, lawyers and the state in Russia and China, 43 Communist ANd Post-Communist Studies 351, 354 (2010); see also Peter H. Solomon, The Accountability of Judges in Post Communist States: From Bureaucratic to Professional Accountability, in Seibert-Fohr, supra note 17, at 909. On judicial government in post-Soviet countries, see also Popova, supra note 17; and Müller, supra note 17 , at 937 .

${ }^{42}$ Kosař, supra note 11.

${ }^{43}$ Kosař, supra note 9 , at 68-72.

${ }^{44}$ Alexei Trochev \& Rachel Ellett, Judges and Their Allies: Rethinking Judicial Autonomy Through the Prism of OffBench Resistance, 2 J. OF L. ANd Courts 67 (2014); MAtTheW C. INGRAM, Crafting Courts IN NeW DemocraCies: The Politics of Subnational Judicial Reform In BRAZIL ANd MeXico (Cambridge University Press 2015); Matthew C. Ingram, Networked Justice: Judges, the Diffusion of Ideas, and Legal Reform Movements in Mexico, 48 J. LAT. AMER. STUD. 739 (2016); Andrea Pozas-Loyo \& Julio Ríos-Figueroa, The Transformations of the Role of the Mexican Supreme Court, In Judicial Politics in Mexico: The Supreme Court and the Transition to Democracy (Andrea Castagnola \& Saúl López Noriega eds., 2016), at 8; Björn Dressel, Raul Sanchez-Urribarri \& Alexander Stroh, The Informal Dimension of Judicial Politics: A Relational Perspective, 13 ANNUAL ReVIEW Of LAW AND SOCIAL SCIENCE 413 (2017); and the special issue on 'Courts and Informal Networks' in Volume 39(5) INTERNATIONAL PolitiCAL SCIENCE REVIEW (2018).

45 James E. Pfander, The Chief Justice, the Appointment of Inferior Officers, and the "Court of Law" Requirement, 107 NorthWEStern University LAW ReVIEW 1125 (2013), and Dawn M. Chutkow, The Chief Justice as Executive: Judicial Conference Committee Appointments, 2 J. OF L. AND COURTS 301 (2014). 
devoted specifically to chief justices of apex courts, especially in the United States, and their selection or dismissal. ${ }^{47}$ Finally, as court presidents tend to fight back when their powers are being curbed, their powers did not escape the attention of both the ECtHR ${ }^{48}$ and other international bodies. ${ }^{49}$

However, all of these scholarly works and policy documents are quite narrowly focused, either on a specific country, on a specific concept such as judicial independence, or on a very specific court president, such as the Chief Justice of the Supreme Court of the United States. What we still lack is an attempt to approach domestic court presidents from a holistic and conceptual point of view that would allow us to compare their functioning across jurisdictions as well as across different tiers of the judiciary within the same jurisdiction.

We know arguably even less about presidents of supranational and international courts. ${ }^{50}$ We can learn some fragments about the role of transnational ${ }^{51}$ court presidents primarily from their speeches, biographies, Festschriften (libri amicorum) and interviews. ${ }^{52}$ Beyond that, there is only a limited literature that attempts to address the role of transnational court presidents in a conceptual way. Importantly, Terris, Romano and Swigart showed

\footnotetext{
${ }^{46}$ See e.g. Ghias, supra note 22; Cristina Bonoan, Alejandro Ciencia \& Björn Dressel, Thrilla in Manilla: Impeachment of the Phillipines' Chief Justice, EAST ASIA FORUM, (March 22, 2012), http://www.eastasiaforum.or $\mathrm{g} / 2012 / 03 / 22 /$ thrilla-in-manila-impeachment-of-the-philippine-s-chief-justice/; Stefanus Hendrianto, The Rise and Fall of Historic Chief Justices: Constitutional Politics and Judicial Leadership in Indonesia, 25 WASHINGTON

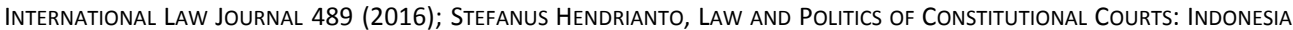
AND THE SEARCH For JUdicial Heroes (2018); and Rohit De \& Tarunabh Khaitan, In Defence of Constitutionalism, ICONNECT (January 19, 2018), http://www.iconnectblog.com/2018/01/ in-defence-of-constitutionalism/.

${ }^{47}$ Pettys, supra note 34. See also Vincze, supra note 1; and Kosař \& Šipulová 2018, supra note 1; Kierulf, supra note 21; and Bonoan, Ciencia \& Dressel, supra note 46.

${ }^{48}$ See e. g. Oleksandr Volkov v. Ukraine, EUR. CT. H. R. (Judgment of 9 January 2013, app. no. 21722/11); Denisov v Ukraine, supra note 15; Olujić v. Croatia, EUR. CT. H. R. (Judgment of 5 February 2009, app. no. 22330/05); Harabin v. Slovakia, EUR. CT. H. R. (Judgment of 20 November 2012, app. no. 58688/11); Baka v. Hungary, EUR. CT. H. R. (Judgment of 23 June 2016, app. no. 20261/12); and Wille v. Liechtenstein, supra note 20.

${ }^{49}$ See e. g. the Opinion No. 19 (2016) of the Consultative Council of European Judges, The Role of Court Presidents, https://rm.coe.int/1680748232; Report on the Independence of the Judicial System, Part I: The Independence of Judges, Venice Commission, CDL-AD(2010)004; or the Opinion on the Draft Law on the Judiciary and the Draft Law on the Status of Judges of Ukraine, Venice Commission, CDL-AD(2007)003.

${ }^{50}$ See Nino Tsereteli \& Hubert Smekal, The Judicial Self-Government at the International Level: A New Research Agenda, in this issue.

${ }^{51}$ We are using the term "transnational courts" so as to cover both international and supranational courts.

${ }^{52}$ See e.g. Fred J. Bruinsma \& Stephan Parmentier, Interview with Mr. Luzius Wildhaber, President of the ECHR, 1 NetH. Q. HUM. RTS. 185 (2003); and Fernanda Nicola \& Bill Davies, Judges as Diplomats in Advancing the Rule of Law: A Conversation with President Koen Lenaerts and Justice Stephen Breyer, 66 AMERICAN UNIVERSITY LAW REVIEW 1159 (2017).
} 
that the presidents of international courts typically serve four distinct functions: judge, administrator, public spokesperson and diplomat. ${ }^{53}$ According to them, especially the last role involves the president in direct and frequent contact with governments (because of, among other things, reporting on the work of the courts and securing funds and other resources), which requires a delicate balance between the judicial and political functions of the international court. ${ }^{54}$ Even international relations scholars started to touch upon court presidents only recently, in the context of studies on informal judicial practices at international courts ${ }^{55}$ and international judicial diplomacy. ${ }^{56}$ These studies reveal

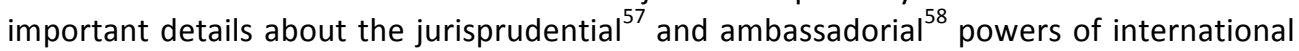
court presidents, but none of these studies focuses primarily on court presidents.

Beyond the United States, ${ }^{59}$ there is not much theorizing about court presidents in the scholarly literature and, if there is, it concerns primarily CEE countries. For instance, several scholars argued, explicitly or implicitly, that Eastern European court presidents naturally wield more power than their counterparts in Western Europe. ${ }^{60}$ However, we still do not know whether this claim can be generalized to all jurisdictions in these two regions and why it is so. ${ }^{61}$ Court presidents play some role in Daniela Piana's "two-wave-theory" of CEE

${ }^{53}$ Daniel Terris, Cesare Romano \& Leigh Swigart, THE INTERNATIONAL JUDGE: AN INTRODUCTION TO THE MEN AND WOMEN WHO DECIDE THE WORLD'S CASES 159 (2007).

${ }^{54}$ Ibid.

${ }^{55}$ See Jeffrey L. Dunoff \& Mark A. Pollack, International Judicial Practices: Opening the 'Black Box' of International Courts, MicHIGAN JOURNAL OF INTERNATIONAL LAW (forthcoming).

${ }^{56}$ See Theresa Squatrito, Judicial Diplomacy: International Courts and their Agents on a Mission (paper presented at ECPR General Conference in Hamburg on 23 August 2018). See also Nicole de Silva, Beyond Adjudication: International Courts' Agency and Entrepreneurship in Governance (paper presented at LSA conference in Toronto on 7 June 2018).

${ }^{57}$ For instance, the ICJ President takes the lead in framing the ICJ judgment as she circulates the list of issues that she thinks should be addressed in the judgment after the oral hearing, she speaks last at the deliberation of judges and indicates her views of the arguments and rationales that enjoy majority support, and she sits automatically (unless she is in the minority) in the three-person judgment drafting committee. For further details, see Dunoff \& Pollack, supra note 55.

${ }^{58}$ For instance, the ICJ President has been issuing an annual report since 1968, has been presenting this report at the regular session of the UN General Assembly, and initiated a practice of providing a private briefing to the Security Council on the pending cases in 2000 (see Dunoff \& Pollack, supra note 55).

${ }^{59}$ But even there the scholarship focuses primarily on the office of the Chief Justice of the Supreme Court of the United States (see in particular Danelski \& Artemus Ward, supra note 34; and literature in note 34) and to a large extent neglects the role of lower federal courts and state courts presidents.

${ }^{60}$ See in particular Solomon 2012, supra note 41, at 918; Müller, supra note 17; Kosař, supra note 9, at 390; and Anna Wallerman, Review of David Kosař, Perils of Judicial Self-Government in Transitional Societies, 55 COMmON MARKET LAW RevieW 676, 677 (2018). For further literature, see Part D.

${ }^{61}$ We revisit this claim in Part $D$. 
judicial councils. ${ }^{62}$ This theory argues that those actors who emerged as winners from the first "transition wave" of judicial reforms (between 1989 and 1997), the Ministry of Justice or the judicial council (often composed of or under the influence of court presidents), were better placed in the second "pre-accession wave" (between 1998 and 2006) of judicial reforms and exploited the opportunities provided by the European Union to entrench existing domestic allocations of power. ${ }^{63}$ Court presidents play an even more prominent role in Kosař's judicial leadership theory of CEE judicial councils. According to this theory, the introduction of the strong judicial council model of court administration into a bureaucratic CEE judiciary in the medium term empowers judicial leadership, namely court presidents, who then use their newly accrued powers to punish their critics and reward their allies within the judiciary in order to preserve their privileges and influence. ${ }^{64}$ Finally, Kosar used the "bargaining in the shadow of the law" metaphor in examining how Czech court presidents, step by step, managed to erode the Minister of Justice's sphere of influence in court administration and have themselves become the most powerful figures within the Czech judiciary. ${ }^{65}$

To summarize this part, we know that court presidents may wield significant power and play various roles, both within their courts and vis-à-vis external actors. We also know that court presidents are particularly strong in some Eastern European countries, where they may, under some circumstances, become the masterminds of their judiciaries. However, we lack thorough understanding of the nature of court presidents' competences. Nor do we know in what ways and to what extent the role of court president actually differs between Western and Eastern Europe, as all studies to date focused only on a very limited set of jurisdictions. In order to answer these questions in the next two Parts we first conceptualize the powers of court presidents and then we compare how important they are as players in 13 European jurisdictions. Finally, in Part D we identify contingent circumstances that may affect the exercise of these powers in practice.

\section{B. Powers of Court Presidents}

We have suggested above that court presidents, although often overlooked, may become quite strong and influential actors within their judiciaries. This claim naturally begs the question what the nature of their power is and in what areas it materializes. In order to

\footnotetext{
${ }^{62}$ See in particular Piana, supra note 37 , at $43-44$.

${ }^{63}$ See Daniela Piana, The Power Knocks at the Courts' Back Door - Two Waves of Postcommunist Judicial Reforms, 42 Comparative Political Studies 816 (2009); and Piana, supra note 37, at 162-165. Note that other scholars have shown that Piana's two-wave theory does not work in all CEE countries. See Kosař, supra note 9, at 10-11 (on Slovakia).

${ }^{64}$ Kosař, supra note 9 , at $16-19$ and 398-405.

${ }^{65}$ See Kosař, supra note 11 (on Czechia).
} 
answer this question we unpack the power of court presidents into seven smaller components and show how court presidents may exploit them. While we eventually argue that these components are interconnected and that these "subpowers" of court presidents should be viewed holistically, we find this "unpacking exercise" necessary, because it allows us to compare European judiciaries in Part $C$ in a far more nuanced way than without it.

However, we need to add three important caveats here. First, we are not claiming that every court president has all of these powers. Our aim is to conceptualize the potential powers that court presidents may have. Whether a particular court president actually enjoys these powers depends, among other things, on the legal framework in a particular jurisdiction, on the prevailing political and legal culture, and on the tier of the judiciary he sits on. Second, we do not limit our analysis merely to conceptualization of formal powers. Many of the powers discussed below are informal. However, we find them equally important for understanding the scope of power of court presidents in each jurisdiction. ${ }^{66}$ Third, we leave aside presidents of administrative courts and special tribunals.

\section{Power over Judicial Careers}

By far the most important power that court presidents in many countries wield is the power over the career of rank-and-file judges. Their influence over such career may start at the very beginning of it with powers over the selection and appointment of judges that can range from informal influence over the bodies that select judges to direct power, both formal and informal, to pick judges by themselves. ${ }^{67}$ The typical examples of an indirect, albeit formal, power can be found at the ECtHR and the CJEU. The President of the ECtHR is consulted on appointments to the Advisory Panel that monitors the election of judges. ${ }^{68}$ The President of the CJEU plays an even greater role as he alone proposes members to the Article 255 TFEU panel and also defines its operating rules. ${ }^{69}$ Irish court presidents also have significant influence over the selection of judges, as they have a seat on the Judicial

\footnotetext{
${ }^{66}$ For a comprehensive explanation of why informal powers are important, see Dressel, Sanchez-Urribarri \& Stroh, supra note 44

${ }^{67}$ Understandably, in some countries, court presidents have little or no influence over selection of judges. For instance, in Romania it is the National Institute of Magistracy, which is coordinated by the Superior Council of Magistracy, that is responsible for recruiting and training new judges. The Superior Council of Magistracy is strongly anti-hierarchical and court presidents have little influence within it. See Bianca Selejan-Guțan, Romania: Perils of a "Perfect Euro-Model" of Judicial Council, in this issue; and Bogdan lancu, Perils of Sloganised Constitutional Concepts, Notably that of 'Judicial Independence', 13 EUROPEAN CONST. LAW R. 582, 594 (2017).

${ }^{68}$ Shai Dothan, The Motivations of Individual Judges and How They Act as a Group, in this issue.

${ }^{69}$ Krenn, supra note 26; and Dothan, supra note 68. Note also that according to the Art. 255 TFEU the European Parliament proposes one member, which is than included by the President of the CJEU in the list of Panel members appointed by the Member States.
} 
Appointments Advisory Board that proposes to the Minister of Justice a list of candidates for the office of judge. Even though the Minister does not have to pick from that list, it is a strong social convention. ${ }^{70}$

In other countries, court presidents may even become the principal gatekeepers to the judiciary. For instance, in Czechia ${ }^{71}$ it is formally the Minister of Justice who selects judges and the Czech President who appoints them, but in practice court presidents of the regional and apex courts are the ones who de facto handpick the judges to "their" courts. ${ }^{72}$ As detailed substantive criteria for the selection of judges are lacking ${ }^{73}$ it fell to the court presidents to sift through the potential candidates and pick the ones who may eventually end up at their court, giving them substantial power. ${ }^{74}$ This not only allows court presidents to shape the judiciary by favoring the candidates who share their views, but also gives them significant leverage over these newcomers on the bench as the selected candidates may feel that they owe loyalty to the court president who actually picked them. ${ }^{75}$ But this phenomenon is not unique to Czechia. Court presidents in Slovenia ${ }^{76}$ and Slovakia ${ }^{77}$ also de facto guard the entrance to the judiciary, notwithstanding the fact that a judicial council exists in both countries.

But court presidents' power over the careers of rank-and-file judges does not necessarily end with the selection of a new judge. On the contrary, rank-and-file judges may depend on court presidents even more, as the latter may have a significant say in the promotion of judges to higher courts. In fact, this is a common practice in Europe. In France, court

\footnotetext{
${ }^{70}$ Patrick O'Brien, Never let a Crisis go to Waste: Politics, Personality and Judicial Self-Government in Ireland, in this issue.

${ }^{71}$ Zdeněk Kühn, Judicial Administration Reforms in Central-Eastern Europe: Lessons to be Learned, In Seibert-Fohr, supra note 17, at 603, 612; and Kosař, supra note 11, at 97 and 100.

${ }^{72}$ For further details on the selection of judges, see Kosař, supra note 9, at 188-191 and 215-216.

${ }^{73}$ The only legal requirements for being appointed a judge are the following general criteria: the Czech nationality, the age of thirty, a clean criminal record, a negative lustration certificate, legal education, and three years of practice.

${ }^{74}$ MoJ has tried to wrestle some of the power back in 2017 by issuing, probably unconstitutional, instructions detailing the criteria and the process of selection and training of the candidates.

${ }^{75}$ This arguably makes these newly selected judges, handpicked by court presidents, more susceptible to eventual pressure by court presidents, which in turn has a potentially negative impact on judicial independence.

${ }^{76}$ Matej Avbelj, Contextual Analysis of Judicial Governance in Slovenia, in this issue.

${ }^{77}$ Samuel Spáč, Katarína Šipulová \& Marína Urbániková, Capturing the Judiciary from Inside: The Story of Judicial Self-Governance in Slovakia, in this issue. But note that presidents of regional courts have greater influence than presidents of district courts.
} 
presidents assess judges by themselves; ${ }^{78}$ in Slovenia they chair the Personnel Councils that peer-review judges and make recommendations as to their career advancement; ${ }^{79}$ and in Slovakia they decide on the composition of the committees that promote judges and on secondments, which significantly increases judge's chances of being promoted. ${ }^{80}$ In Germany court presidents chair the Presidential Councils (Präsidialräte) that write a statement on the qualities of judges up for promotion. ${ }^{81}$ This is something German rankand-file judges may take into account when deciding cases. More specifically, it has been reported that judges who seek promotion may be tempted to adjust their decision-making according to the views of their court presidents and that maverick judges may be denied promotion. $^{82}$ If this may happen in Germany, it is highly likely that similar considerations are taken into account in other jurisdictions too.

To be sure, court presidents are not accidentally given this power over judicial selection and promotion. They are actually the ones who have the best overview of what is going on within their courts, what kind of judge they need to complement their "team", and what the strengths and weaknesses of each rank-and-file judge are. For the very same reason, court presidents are also the ones who may and most often do subject judges to accountability mechanisms ${ }^{83}$ such as disciplinary proceedings, ${ }^{84}$ case-assignment and reassignment, ${ }^{85}$ and periodic judicial performance evaluation. ${ }^{86}$ All of these accountability mechanisms may, each in its own way, affect the career of a rank-and-file judge.

\section{Administrative Power}

\footnotetext{
${ }^{78}$ Antoine Vauchez, The Strange Non-Death of Statism: Tracing The Ever Protracted Rise of Self-Government in France, In this issue; Antoine Garapon \& Harold Epineuse, Judicial Independence in France, in Seibert-Fohr, supra note 17 , at $273,285-286$.

${ }^{79}$ Avbelj, supra note 76. See especially the citation of a resignation letter by the former Judicial Council member, Nevenka Šorli, who claimed that it is the Personnel Councils that make the decision on promotion of a judge.

${ }^{80}$ Spáč, Šipulová \& Urbániková, supra note 77.

${ }^{81}$ Anja Seibert-Fohr, Judicial Independence in Germany, in Seibert-Fohr, supra note 17, at 447, 460.

${ }^{82}$ See Stephen Ross Levitt, The Life and Times of a Local Court Judge in Berlin, 10 GeRMAN L.J. 169, 197-8 (2009); and Seibert-Fohr, supra note 81, at 502.

${ }^{83}$ For taxonomy of these mechanisms, see Kosař, supra note 9, at 73-120.

${ }^{84}$ This is the case in Czechia, Slovakia or France; see Kosař, supra note 9, at 214, 234; Spáč, Šipulová \& Urbániková, supra note 77; and Garapon \& Epineuse, supra note 78, at 292.

${ }^{85}$ Spáč, Šipulová \& Urbániková, supra note 77; Kosař, supra note 9, at 212, 232.

${ }^{86}$ This is the case of Romania or Slovenia, see Gutan, supra note 67; and Avbelj, supra note 76.
} 
Court presidents may affect not only the careers of rank-and-file judges, but also their everyday lives and work. They often have broad managerial powers that can be used quite effectively. Most importantly they may decide what cases, and how many, each judge at their courts will deal with. This can be done either by deciding in what chamber a judge will sit or through the power to assign cases.

The composition of a panel matters in all jurisdictions. ${ }^{87}$ If a court president may reshuffle the panels according to her liking, she may influence the dynamics within the panels and sometimes even change the outcome of a case. ${ }^{88}$ However, assigning to a chamber or a panel $^{89}$ matters even more when judges are not generalists and the chambers are specialized in some area of law. ${ }^{90}$ Typically, courts have separate civil and criminal divisions, but sometimes the specialization of judges goes much further and the special chambers focus on a very narrow area of law, such as bankruptcy law, intellectual property law or competition law. In such scenario, court presidents de facto decide on the specialization of rank-and-file judges at their courts and may even repeatedly force them to adjust to the new area of law, which can be frustrating at times.

Case assignment is an even more straightforward technique. If a court president can assign cases on a discretionary basis ${ }^{91}$ or can at least influence the mechanism of distribution of cases, she may achieve the same ends. The comparative analysis shows that random case assignment coupled with the possibility for a rank-and-file judge to challenge the allegedly improper assignment of a particular case exists only in few jurisdictions covered by this special issue. ${ }^{92}$ In most countries, court presidents can either assign cases on a discretionary basis, or they determine ${ }^{93}$ (or at least heavily influence) ${ }^{94}$ the rules (typically

\footnotetext{
${ }^{87}$ For a recent example beyond Europe, see the controversial actions of the Chief Justice of India in De \& Khaitan, supra note 46.

${ }^{88}$ See also below on the jurisprudential powers of court presidents.

${ }^{89}$ E.g. in Italy, Czechia, Netherlands, see Simone Benvenuti \& Davide Paris, Judicial Self-Government in Italy: Merits, Limits and the Reality of an Export Model, in this issue; Adam Blisa, Tereza Papoušková \& Marína Urbániková, Judicial Self-Government in Czechia: Europe's Black Sheep?, in this issue; and Elaine Mak, Judicial SelfGovernment in the Netherlands: Demarcating Autonomy, in this issue.

${ }^{90}$ Kosař, supra note 9 , at 80 .

${ }^{91}$ France, see Garapon \& Epineuse, supra note 78, at 288.

92 See e. g. Germany, see Siebert-Fohr, supra note 81, at 486; and Fabian Wittreck, German Judicial SelfGovernment: Institutions and constraints of self-government in Germany, in this issue.

${ }^{93}$ Czechia, Ireland, Italy, France, Netherlands and others, see Blisa, Papoušková \& Urbániková, supra note 89; O'Brien, supra note 70; Vauchez, supra note 78; and Mak, supra note 89.

${ }^{94}$ Cf. Slovakia, in which cases are since 2002 assigned randomly by a computer, see Spáč, Šipulová \& Urbániková, supra note 77.
} 
in the so-called "work schedule") of case assignment. Moreover, even in countries that established random initial case assignment court presidents may exploit the loopholes within this system, ${ }^{95}$ override the initial case assignment and reassign the case to another judge. $^{96}$

The crucial nature of these two powers is obvious, because by simply assigning a judge to a specific chamber a court president can determine her specialization for the future, and assigning a judge to a chamber dealing with cases outside her specialization can even be used as a powerful tool for punishing a recalcitrant judge. ${ }^{97}$ Similarly the power to assign cases, when purely discretionary, can be used as a tool to reward or punish by distributing cases unevenly according to their difficulty, number, political salience and other criteria. However, in those countries where the right to a legal judge (gesetzlicher Richter) has constitutional rank, ${ }^{98}$ the power of court presidents to tinker with case assignment is substantially reduced or even eliminated. ${ }^{99}$

With the rise of new public management and the growing emphasis on the speediness of justice, court presidents also increasingly set caseload quotas and police their fulfillment. ${ }^{100}$ This control often goes beyond the mere checking of the number of cases disposed of and may materialize into a full-fledged regulation of case-flow and judicial performance evaluation. Through these mechanisms court presidents may motivate slower judges, but they may also exercise inappropriate pressure that impinges upon the core judicial values ${ }^{101}$ or create a "culture of numbers" that may result in output perversions. ${ }^{102}$

Finally, court presidents also possess other administrative powers that do not have a direct bearing on decision-making, but still have a significant impact on the day-to-day work of

\footnotetext{
${ }^{95}$ Similar mechanism exists in Romania, but is not allegedly completely resistant to rigging, see Coman \& Dallara, supra note 36 , at 862 .

${ }^{96}$ On Harabin in Slovakia, see Kosař, supra note 9, at 320-321, 327-329. See also recent Indian controversy in India in De \& Khaitan, supra note 87.

${ }^{97}$ Kosař, supra note 9, at 81; and Popova, supra note 41, at 136-138.

${ }^{98}$ E. g. in Germany or Czechia. See Seibert-Fohr, supra note 81, at 481-483; or David Kosař, Rozvrh práce: Klíčový nástroj pro boj s korupcí soudců a nezbytný předpoklad nezávislosti řadových soudců, 154 PRÁvNík 1049 (2015).

${ }^{99}$ This goes especially for the countries with electronic randomized distribution of cases, see supra notes 94 and 95.

${ }^{100}$ E. g. Mak, supra note 89.

101 Tomer Zarchin, Nir Haason \& Yaniv Kubovich, Jerusalem Judge Commits a Suicide Due to Workload, HAARETZ (February 9, 2011), https://www.haaretz.com/1.5119677.

${ }^{102}$ Kosař, supra note 9 , at 70-71.
} 
judges. ${ }^{103}$ First of all, they process complaints against judges. ${ }^{104}$ Second, they hire and dismiss administrative staff at their court (or even courts), ${ }^{105}$ ranging from secretaries to law clerks. ${ }^{106}$ Furthermore, court presidents control or influence the administration of material resources at their courts ${ }^{107}$ and exercise further executive functions. ${ }^{108}$ They also approve judges' travel to conferences and their extrajudicial activities. Simply abusing one of these powers can rarely create more than a nuisance (e.g. giving a judge a small office) and is not capable of a heavy impact by itself but, when cleverly combined, they may have the effect of "death by a thousand cuts" - a judge with a small office, a slow computer with a slow Internet connection, relying on ineffective administrative staff and an incompetent law clerk, overburdened due to unfavorable case assignment mechanisms, may either fold and give in to the pressure of the court president, resign or make a mistake and be potentially exposed to disciplinary proceedings. ${ }^{109}$

\section{Jurisprudential Power}

Court presidents also wield jurisprudential power. If they are leading figures in their field and possess a healthy dose of leadership skills and judicial statesmanship, they may set the courts' agenda and even shape the law. At lower courts, court presidents may influence their younger colleagues, especially at the bureaucratic civil law judiciaries where judicial candidates become judges only a few years after law school and are completely socialized within the judiciary. At apex courts, the court presidents often have additional institutional advantages, such as opinion assignment, deciding on the vote order, third-party interventions ${ }^{110}$ and additional resources, ${ }^{111}$ which they may utilize to set the agenda and promote their preferences. Chief Justices also often automatically sit on the grand

\footnotetext{
${ }^{103}$ Netherlands, Czechia, Slovenia and others, see Mak, supra note 89; Blisa, Papoušková \& Urbániková, supra note 89; and Avbelj, supra note 76.

${ }^{104}$ E.g. in Czechia or Slovakia, see Kosař, supra note 9, at 221-222, 229, 275, 285.

${ }^{105}$ This goes for the Chief Justice of the Supreme Court of the United States, see Pfander, supra note 45, at 11321137.

${ }^{106}$ This is the case of the ECtHR, on legal staff, see Dothan, supra note 68; or Germany, see Seibert-Fohr, supra note 81 , at $456-457$.

${ }^{107}$ Vicki C. Jackson, Judicial Independence: Structure, Context, Attitude, in Seibert-Fohr, supra note 17, at 19, $53-$ 54; Kosař, supra note 9, at 90-91; Popova, supra note 41, at 59; Schwartz \& Sykiainen, supra note 36, at 976.

${ }^{108}$ See Pfander, supra note 45, and Chutkow, supra note 45, at 303-304.

${ }^{109}$ This happened to a certain degree in Slovakia, see Kosař, supra note 9, at 361.

${ }^{110}$ Çalı \& Cunningham, supra note 29.

${ }^{111}$ The extra resources may include, among other things, more law clerks, more secretarial support, and special research divisions; see Kosař, supra note 9 , at 403.
} 
chamber $^{112}$ (or similar extended bodies that unify the case law and decide the most vexing issues) and may even decide on the grand chamber's composition. ${ }^{113}$ All of this gives them additional leverage and distinguishes them from senior judges, who may also have jurisprudential power, but they have to rely solely on their erudition and reputation.

Court presidents may also foster consensual decision-making by skillful framing of cases and alleviating tensions among their colleagues. Vice versa, if they fail to forge consensus, the level of conflict at a given court may skyrocket. This may in turn result in the rise of dissenting and concurring opinions. ${ }^{114}$ This arguably happened at the U.S. Supreme Court after Harlan Fisk Stone was elevated to the position of the Chief Justice (1941-1946). ${ }^{115}$ Studies on changing dissent rates in the Supreme Court of Canada, ${ }^{116}$ the High Court of Australia, $^{117}$ and the Supreme Court of Norway ${ }^{118}$ also found that court leadership is important in explaining variation of dissent over time. Even if separate opinions are not allowed, which is the case for most continental ordinary courts, lackluster leadership has significant jurisprudential effects, albeit less visible than the separate opinions. Failing leadership at lower courts may cause the increase of divergent opinions across courts' various panels, which in turn may increase the burden of the appellate courts, while at apex courts it may require triggering burdensome special procedures to unify such divergent case law. ${ }^{119}$

\footnotetext{
${ }^{112}$ This is the case of virtually all courts where such a body exists.

${ }^{113}$ Czechia, Netherlands (court presidents influence composition of all chambers via Management Board presided by them); see Kosař, supra note 11, at 100; Mak, supra note 89.

${ }^{114}$ Frank N. Cross \& Stefanie Lindquist, Doctrinal and Strategic Influences of the Chief Justice: The Decisional Significance of the Chief Justice, 154 UNIVESITY OF PENNSYLVANIA L. R. 1665 (2006); cited from Henrik Litleré Bentsen, Court Leadership, Agenda Transformation, and Judicial Dissent, 6 JOURNAL OF LAW AND COURTS 189, 192 (2018).

115 David J. Danielski, Causes and Consequences of Conflict and Its Resolution in the Supreme Court, In JUDICIAL CONFLICT AND CONSENSUS: BehavioRAL STUdies OF AMERICAN APPELLATE COURTS (Sheldon Goldman \& Charles M. Lamb eds., 1986), at 21; and Thomas G. Walker, Lee Epstein \& William J. Dixon, On the Mysterious Demise of Consensual Norms in the United States Supreme Court, 50 JournAL OF Politics 361 (1988); both cited according to Bentsen, supra note 114 , at 191-192.

${ }^{116}$ C. L. Ostberg, Matthew E. Wetstein \& Craig R. Ducat, Leaders, Followers, and Outsiders: Task and Social Leadership on the Canadian Supreme Court in the Early 'Nineties, 36 PoLITY 505 (2004); and Donald R. Songer, John Szmer \& Susan W. Johnson, Explaining Dissent on the Supreme Court of Canada, 44 CANADIAN JOURNAL OF POLITICAL SCIENCE 389 (2011); both cited according to Bentsen, supra note 114, at 192.

117 Russel Smyth, Explaining Historical Dissent Rates in the High Court of Australia, 41 COMMONWEALTH AND COMPARATIVE Politics 83 (2003); and Russel Smyth \& Naryan Kumar Paresh, Hail to the Chief! Leadership and Structural Change in the Level of Consensus on the High Court of Australia, 1 JOURNAL OF EMPIRICAL LEGAL STUDIES 399 (2004); both cited according to Bentsen, supra note 114, at 192.

${ }^{118}$ Bentsen, supra note 114, at 194-210.

${ }^{119}$ Such as referral of the case to the Grand Chamber at the ECtHR, see Çalı \& Cunningham, supra note 29; CJEU's President similarly wields substantive power regarding case assignment, see Krenn, supra note 26.
} 
Sometimes court presidents may shape the jurisprudential image even by subtle changes to the rules of the debate among judges. For instance, a court president may deliberately change the internal institutional dynamics of her court by facilitating a more "academic" style of deliberation in which conference discussions are expanded. ${ }^{120}$ As a result, opinion writing and circulation delays become more common and the judges may seize the opportunity to reargue contentious cases.

However, there is also a dark side of the court presidents' jurisprudential power. Instead of shaping the law and persuading their colleagues to steer the courts according to their jurisprudential vision, court presidents can misuse their powers and either silence the critics or even attempt to influence the outcome of individual cases. For instance, in the absence of separate opinions, by assigning a liberal judge to a three-judge panel where she will be regularly overruled by her conservative colleagues a court president can effectively silence certain jurisprudential positions at the court. Similarly, by assigning a case to a judge who a court president knows will decide it in a certain way, be it out of that judge's political views ${ }^{121}$ or sheer loyalty to the court president, the court president may bend the case law in the direction she wants. To name one more example, the Chief Justice of the Slovak Supreme Court "contained" his critics in two chambers of the administrative law division which dealt only with disputes with limited policy implications, and hence his critics could not influence the case law of the Supreme Court in important areas of law. ${ }^{122}$ In the worst case scenario, a court president may become a "transmission belt"123 of powerful political and business actors and rig the court according to their will. ${ }^{124}$

\footnotetext{
${ }^{120}$ This is what the Chief Justice of the U.S. Supreme Court Harlan Fisk Stone did in the 1940's, see PAMELA C. Corley, Amy SteigerWalt \& ARTemus Ward, THe PuZZle of UnANimity: Consensus on the United States Supreme Court (2013), cited according to Bentsen, supra note 114, at 192. Fifty years later, Carsten Smith did the same once he became the Chief Justice of the Supreme Court of Norway, see Bentsen, supra note 114, at 196-198.

${ }^{121}$ Wood, Lanier, Keith \& Ogundele, supra note 34 , at 800 and $805-808$, find that this so-called attitudinal model of case assignment is not supported by data at the Supreme Court of the United States; but see also Maltzman \& Wahlbeck 1996, at 421-425; Maltzman \&Wahlbeck 2004; Maltzman; White; and Lax \& Cameron, all supra note 34 , who found that organizational needs are a strong factor in case assignment, but the attitudinal (i.e. ideological proximity) factor also played some role.

${ }^{122}$ Kosař, supra note 9 , at 320-321.

123 The "transmission belt" metaphor suggests that court presidents, who could be recalled by the ruling party/individual anytime at a whim, become the conduit of the ruling party/individual influence over individual judges. The main role of the court presidents is then to "transmit" orders from the ruling party/individual to individual judges in sensitive cases. See e.g. Kosař, supra note 11, at 101, 105, 117, and 121-122; and Rachel Ellett, Raul Sanchez Urribarri \& Alexei Trochev, Chief Justice as a Political Agent: Evidence from Zambia, Venezuela, and Ukraine, paper presented at the ECPR General Conference in Prague on 9 September 2016 (on file with author).

${ }^{124}$ Popova, supra note 41, at 163; and Alexei Trochev, Meddling with Justice: Competitive Politics, Impunity, and Distrusted Courts in Post-Orange Ukraine, 18 DemokratizaTsiYa 122, 133 (2010).
} 


\section{Financial Power}

Resources are crucial for courts and judges alike, and equally crucial is the power to distribute them. Courts need to finance their day-to-day functioning, and it is often in the hands of court presidents to manage the courts' budgets. ${ }^{125}$ Furthermore, although it would be surprising to find a country where court presidents have complete power over judicial salaries, they often have at least some say in distributing salary supplements, bonuses or other non-monetary perks. ${ }^{126}$

For example, in Russia and Ukraine court presidents decide on various ancillary issues such as the allocation of subsidized housing and deciding on judges' vacation packages. As judges in these two countries are often entitled to subsidized housing, and, since the available housing is not unlimited and not all housing is equal, this perk is often used by court presidents to please or intimidate judges. ${ }^{127}$ "Disloyal" judges thus can be denied an apartment for several years or "can suddenly face eviction or transfer to another apartment, which in the best-case scenario is a huge hassle". ${ }^{128}$ In fact, Russian and Ukrainian court presidents have even wider powers and may help judges with other perks that affect their well-being, such as judges' vacation packages and access to day care for their children. ${ }^{129}$

The European countries covered by this special issue leave generally less room for court presidents to affect the extrajudicial lives of rank-and-file judges, but in some postcommunist countries, such as Slovakia, court presidents have managed and used these non-monetary benefits to reward and punish judges. ${ }^{130}$

\section{Ambassadorial Power}

Another important activity of court presidents is interaction with the outside world, be it the public or the other branches of power, which they can use to lobby for their interests or for the interests of their courts, the judicial branch or even their country. This

\footnotetext{
${ }^{125}$ This is the case of Czechia, or, to some degree, of Netherlands, where court presidents implement court's budget through the Management Boards; see Blisa, Papoušková \& Urbániková, supra note 89, and Mak, supra note 89.

${ }^{126}$ E.g. Slovakia, see Spáč, Šipulová \& Urbániková, supra supra note 77.

${ }^{127}$ See Popova, supra note 41, at 134.

${ }^{128} / d$.

${ }^{129}$ See Solomon 2010, above note 41, at 354; or Solomon 2012, supra note 41, at 912.

${ }^{130}$ See Kosař, supra note 9 , at 361 and 369.
} 
"ambassadorial" power may stem both from their legally prescribed duties and from the convention. This power is particularly elastic and depends heavily on the personality and political savviness of the court president as well as on the respective political and legal culture.

For instance, the Presidents of both the $\mathrm{CJEU}^{131}$ and the ECtHR ${ }^{132}$ can serve as examples of this power, as both of them are supposed to represent their courts, and indeed use this role extensively. Similarly, virtually all major judicial figures in Australia, Canada, New Zealand and the United Kingdom engage in international diplomacy and regularly give speeches primarily (but not exclusively) in other Commonwealth countries. ${ }^{133}$ So does the Chief Justice of the Supreme Court of the United States who also publishes an annual yearend report on the state of the federal judiciary in which he can raise various issues to be tackled by the judiciary and other branches. ${ }^{134}$ Italy serves as yet another example. Here the first president of the Corte Cassazione makes a speech on the occasion of the opening of the judicial year in the presence of, among other dignitaries, the President of the Italian Republic and other key public officials. This is not just a ceremonial meeting as, after the speech, the two go into a deep discussion on the issues related to the functioning of the justice system. ${ }^{135}$

However, ambassadorial power may sometimes put court presidents on a collision course with political branches. This was the case of the Hungarian Supreme Court President András Baka who was ex lege also the chairman of the National Judicial Council. As the President of the National Council of Justice, he was under an explicit statutory obligation to express an opinion on draft legislation that affected the judiciary. ${ }^{136}$ Once Viktor Orbán presented his controversial judicial reforms, András Baka became a vocal critic of these reforms and repeatedly addressed the Parliament and other bodies where he contended

\footnotetext{
${ }^{131}$ See Krenn, supra note 26, and his description of the role of the then Court President Skouris in the institutional reform of the General Court. Moreover, the CJEU's Court President has the power to further shape the image of the Court in that external activities of judges are subject to prior approval by their peers, and the Court President has quite a significant say in this.

${ }^{132}$ Çalı \& Cunningham, supra note 29, describe the role of the then ECtHR's President Jean-Paul Costa in the introduction of the Advisory Panel and the suggested influence over its composition.

${ }^{133}$ See e. g. P. Y. Lo, Chief Justice McLachlin and Hong Kong, I-CONNECT (October 1, 2017), http://www.iconnect blog.com/2017/12/lo-on-chief-justice-mclachlin/; for speeches of the Justices of the High Court of Australia see http://hcourt.gov.au/publications/speeches/speeches-by-current-justices; for speeches by the judges from New Zealand see https://courtsofnz.govt.nz/publications/speeches-and-papers; and others.

${ }^{134}$ See Chief Justice's Year-End Reports on the Federal Judiciary, https://www.supremecourt.gov/publicinfo/yearend/year-endreports.aspx.

${ }^{135}$ Benvenuti \& Paris, supra note 89.

${ }^{136}$ Baka v. Hungary, supra note 48 , para 44.
} 
that the new laws negatively affected the judiciary. Orbán's regime apparently did not like it and eventually passed a constitutional amendment that de facto dismissed András Baka from both functions and allowed Orbán to replace Baka with more loyal persons. ${ }^{137} \mathrm{~A}$ similar scenario has taken place in Poland, where the Law and Justice Party wants to get rid of the Polish Supreme Court President, Małgorzata Gersdorf, ${ }^{138}$ who stood up against the attempts to curb the Supreme Court. ${ }^{139}$

However, such firm stance against controversial judicial reforms may also increase the ambassadorial power of court presidents abroad as they become a moral symbol of defiance against the populist political leaders and their abusive techniques. It did not eventually help András Baka, but the recent actions of the EU organs regarding the Polish judicial reforms suggest that Małgorzata Gersdorf has used her ambassadorial power well. $^{140}$

\section{Media Power}

Court presidents use a plethora of tools to communicate with various audiences, including press releases, social media, special events, and YouTube. ${ }^{141}$ They also enjoy unprecedented access to the media as they are perceived as speaking on behalf of the judiciary. By engaging with the journalistic press court presidents can even shape the public image of the judiciary. For instance, the Chief Justice of the Supreme Court of Canada, Beverley McLachlin, regularly talks to the press, initiated a now-traditional question and answer with television media following her annual address at the Canadian Bar Association, and hosts an annual open-door celebration at the Supreme Court on Canada Day. ${ }^{142}$ She also learned how important media power is when she was forced to

\footnotetext{
${ }^{137}$ For further details, see Kosař \& Šipulová2018, supra note 1.

${ }^{138}$ See note 5 above.

${ }^{139}$ See note 5 above.

${ }^{140}$ See Case C 216/18 PPU Minister for Justice and Equality v LM; and the "The CJEU's Deficiency Judgment" symposium at the Verfassungsblog (https://verfassungsblog.de/category/focus/after-celmer-focus/). See also the other two pending cases initiated by the European Commission before the CJEU (Case C-192/18, Commission v. Poland, pending; and Case C-619/18, Commission v. Poland, pending). In December 2017, the European Commission also launched the so-called Article 7 proceedings against Poland over changes to the judicial system.

${ }^{141}$ See. e. g. Jeffrey K. Staton, Judicial Power and Strategic Communication in Mexico (2010); Shal dothan, Reputation and Judicial Tactics (2015); Georg Vanberg, The Politics of Constitutional ReView in Germany (2005);

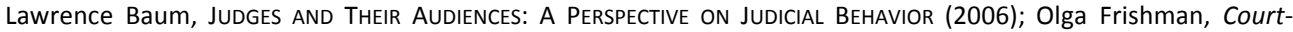
Audience Relationships in the $21^{\text {st }}$ Century, MISSISSIPPI LAW JOURNAL (forthcoming); NUNO GAROUPA \& TOM GINSBURG, JUdicial RePUTATION: A COMPARATIVE THeORY (2017); the CCJE also lists "maintaining and developing relations with other bodies and institutions" as one of the key roles of the court president, see supra note 49.

${ }^{142}$ Lawrence David, The Face of and Institution: Beverly McLachlin's Reinvention of the Role of the Chief Justice of Canada, I-CONNECT (December 8, 2017), http://www.iconnectblog.com/2017/12/david-on-chief-justicemclachlin/.
} 
defend herself against allegations by the then Prime Minister of Canada, Stephen J. Harper, of having improperly interfered with the nomination of Marc J. Nadon, ${ }^{143}$ a Federal Court of Appeal judge who was later disqualified from appointment on the basis of his ineligibility for one of three Supreme Court seats reserved for the province of Quebec. ${ }^{144}$ The witty use of media power is no less important in emerging democracies. ${ }^{145}$

In Europe, court presidents are also vocal in the media. Presidents of supranational courts have been particularly active in this regard. Koen Lenaerts, the president of the CJEU, regularly provides interviews and engages with the press. ${ }^{146}$ Most ECtHR presidents do so too. Luzius Wildhaber and Jean-Paul Costa were particularly outspoken in press conferences and interviews. ${ }^{147}$ Domestic court presidents have not been left behind. They often employ press officers to handle the media for day-to-day information about the outcomes of cases, ${ }^{148}$ but they make sure that these press releases are coherent with their vision of their court. However, the media power of court presidents often goes further. For instance, the Czech apex court presidents receive substantial media attention that they use to gather political support as well as a tool in the interaction with political actors. ${ }^{149}$ Sometimes court presidents use the media to expose disagreement among themselves ${ }^{150}$

${ }^{143}$ Sean Fine, The secret short list that provoked the rift between Chief Justice and PMO, THE GLOBE AND MAIL (May 23, 2014), https://www.theglobeandmail.com/news/politics/the-secret-short-list-that-caused-a-rift-betweenchief-justice-and-pmo/article18823392/.

${ }^{144}$ Reference re Supreme Court Act, ss. 5 and 6, [2014] 1 S.C.R. 433, 2014 SCC 21. For further details, see Carissima Mathen. The Shadow of Absurdity and the Challenge of Easy Cases: Looking Back on the Supreme Court Act Reference, 71 SUPREME CoURT LAW REVIEW 161 (2015).

${ }^{145}$ See e.g. Stefanus Hendrianto, The Puzzle of Judicial Communication in Indonesia: The Media, the Court, and the Chief Justice, In Justices ANd Journalists: The Global PeRSPECTIVE 141 (Richard Davis \& David Taras eds., 2017).

${ }^{146}$ See e.g. Duncan Robinson \& Alex Barker, EU's top judge defends ECJ against charges of integration agenda, FINANCIAL TIMES (November 22, 2016), https://www.ft.com/content/0e132ef8-af0c-11e6-a37c-f4a01f1b0fa1.

${ }^{147}$ WojCIECH SADURSKI, CONSTITUTIONALISM AND THE ENLARGEMENT OF EUROPE (2012), at 1. For Wildhaber's vision of the Strasbourg Court, see Luzius Wildhaber, The European Court of Human Rights: The Past, The Present, The Future. 22 AMERICAN UNIVERSITY INTERNATIONAL LAW REVIEW 521 (2007).

${ }^{148}$ E. g. Germany, see Seibert-Fohr, supra note 81, at 506.

${ }^{149}$ The Supreme Administrative Court's President, Josef Baxa, is a regular guest of radio show called How He Sees It, and the Constitutional Court's Chief Justice Pavel Rychetský frequently gives interviews on topics ranging from the judicial to the purely political ones; see e. g. Martin Biben \& Markéta Šrajbrová, Prezident nemúže protahovat vládnutí kabinetu bez důvěry neomezeně, HOSPODÁŘSKÉ NOVINY (November 1, 2017), https://archiv.ihned.cz/c165935270-prezident-nemuze-protahovat-vladnuti-kabinetu-bez-duvery-neomezene-hrozi-mu-ustavni-zalobatvrdi-rychetsky; or Kristýna Novotná, Mám obavy ze Zemanovy kohorty panošů, Ovčáčka by měli na hodinu vyhodit, řiká šéf Ústavniho soudu Rychetský, IRozHLAS (January 8, 2018), https://www.irozhlas.cz/zpravydomov/pavel-rychetskymilos-zemanjiri-ovcacek_1801080600_ogo. Note that in the polls assessing the popularity of public officials, Rychetský often comes out on top of the ladder.

${ }^{150}$ Franck Johannès, Le premier président de la Cour de cassation s'inquiète du pouvoir croissant du Conseil d'Etat, LE MONDE (December 21, 2015), https://www.lemonde.fr/police-justice/article/2015/12/21/le-premier-president- 
and even to criticize each other. The rapid development of social media such as Facebook or Twitter also provided court presidents with an opportunity to further boost their media power, because they can use the new platforms to communicate directly with their intended audiences and set their agenda without the need to rely on traditional media to "get it right". ${ }^{151}$

\section{Ancillary Powers}

In some countries court presidents also have various ancillary powers that do not directly concern judicial decision-making or the functioning of their courts stricto sensu and cannot be put into some of the categories mentioned above. This does not mean, however, that these powers are negligible. For instance, the Chief Justice of the Supreme Court of Canada, beyond her additional roles, also chairs the committee which advises the Governor General on awards of membership of the Order of Canada ${ }^{152}$ as well as the Board of Governors of the National Judicial Institute, which develops and delivers various educational programs for all Canada's federal, provincial and territorial judges. ${ }^{153}$ Furthermore, the Chief Justice of the Supreme Court of Canada appoints a substitute Chief Electoral Officer in case of her negligence or death or incapacity while Parliament is not sitting. ${ }^{154}$ What is more, should the Governor General die, become incapacitated, be removed or be absent from the country for a period of more than one month, the Chief Justice would become the Administrator of Canada and exercise all the powers and authorities of the Governor General. ${ }^{155}$

Importantly, court presidents often sit on or even chair JSG bodies. In the Netherlands, court presidents chair the management boards established at each court. ${ }^{156}$ Similarly, Slovenian court presidents preside over personnel councils. ${ }^{157}$ In Ireland, the Judicial

de-la-cour-de-cassation-s-inquiete-du-pouvoir-croissant-du-conseil-d-etat_4835887_1653578.html. For further background of this rare public disagreement between the First President of the French Cour de Cassation Bertrand Louvel and the Vice-President of Conseil d'État over the dualism of the French judiciary, see MarieChristine de Montecler, Duel à distance sur le dualisme juridictionnel, Dalloz Actualte (July 28, 2017), https://www.dalloz-actualite.fr/flash/duel-distance-sur-dualisme-juridictionnel\#.W-vVLeKNzjw.

${ }^{151}$ See e. g. the Twitter account of the Czech SAC's President Josef Baxa, at https://twitter.com/josefbaxa2.

${ }^{152}$ David, supra note 142.

${ }^{153} / d$.

${ }^{154}$ Canada Elections Act, S.C. 2000, c.9, s. 14(1).

155 About the Judges, SUPREME COURT OF CANADA (August 28, 2017), http://www.scc-csc.ca/judges-juges/aboutapropos-eng.aspx.

${ }^{156}$ Mak, supra note 89.

${ }^{157}$ Avbelj, supra note 76. 
Appointments Advisory Board (JAAB) is chaired by the Chief Justice and the president of each court is a member ex officio, which gives court presidents a significant influence in the JAAB. ${ }^{158}$ In Germany, court presidents sit on presidia, councils of judicial appointment and in some Länder even on committees for the selection of judges. ${ }^{159}$ The President of the Supreme Court presides over the judicial councils in Spain ${ }^{160}$ and France. ${ }^{161}$

In contrast, the CEE countries initially allowed court presidents to sit on judicial councils, but then they retreated due to problems with the accumulation of too much power. For instance, Poland banned court presidents from membership of the National Council of the Judiciary in 2007. ${ }^{162}$ The Slovak Parliament adopted the same incompatibility rule in 2011, and later on even stripped the Supreme Court President of chairmanship of the judicial council. ${ }^{163}$ Until 2014 the Chief Justice of the Slovak Supreme Court also chaired the Judicial Council of the Slovak Republic. Only in the wake of the authoritative rule of the Supreme Court President, Štefan Harabin, who used the carrots to reward his allies within the judiciary and ruthlessly employed the available sticks against his critics, Slovakia split these two positions among two different persons. ${ }^{164}$ To make things even more complex, the separation of the positions of the chairman of the judicial council and the Chief Justice of the Supreme Court can also be abused, as the Baka case attests. As mentioned above, the regime of Viktor Orbán used the need to separate these two offices as a lame justification to dismiss András Baka from both of these functions. ${ }^{165}$

\section{The Holistic View of Court Presidents' Powers}

Even though we unpacked the power of court presidents into seven smaller components for the sake of deeper analysis, they should not be understood as isolated from each other. On the contrary, they are interconnected and have a synergic effect. For instance, if court presidents enjoy great powers regarding the careers of rank-and-file judges, this will also likely enhance their jurisprudential power. Similarly, strong administrative and financial

\footnotetext{
${ }^{158}$ O'Brien, supra note 70.

${ }^{159}$ Wittreck, supra note 92.

${ }^{160}$ See Aida Torres Pérez, Judicial self-government and judicial independence: the political capture of the General Council of the Judiciary in Spain, in this issue.

${ }^{161}$ Vauchez, supra note 78.

${ }^{162}$ See Adam Bodnar \& Lukasz Bojarski, Judicial Independence in Poland, In Seibert-Fohr, supra note 17, at 673.

${ }^{163}$ This was the case in Slovakia during the era of the Chief Justice Štefan Harabin (2009-2014). See Spáč, Šipulová \& Urbániková, supra note 77; and Kosař, supra note 9.

${ }^{164}$ See supra notes 1 and $136-137$.

${ }^{165}$ See Spáč, Šipulová \& Urbániková, supra note 77.
} 
powers may also increase court presidents' leverage over rank-and-file judges. ${ }^{166} \mathrm{~A}$ broader jurisprudential power may then buttress the court president's media power. In another scenario, strong media power gives court presidents significant leverage over the bodies formally vested with the power to select and promote judges that in turn may be forced to respect court presidents' views regarding the selection of candidates for judicial office and their subsequent promotion. ${ }^{167}$ As a result, selected candidates, handpicked by court presidents, may feel that they "owe" something to their court presidents for being shortlisted and appointed. This may create a certain bond of loyalty ${ }^{168}$ which court presidents can later on exploit in order to bolster their jurisprudential and administrative powers.

These relationships between the various powers of court presidents are complex and we do not intend to make any causal claims here as this would require a more in-depth study of selected jurisdictions. Such study would also need to analyze the contingent circumstances $^{169}$ of court presidents' powers in each jurisdiction and explore alternative explanations. We merely point out that these relationships exist and should be addressed in future research. ${ }^{170}$

\section{How Strong are Court Presidents in Europe?}

In Part B of this article, we developed a taxonomy of powers of court presidents. In doing so we built on the contributions in this special issue as well as on examples from all over the globe. In this Part we narrow the number of studied jurisdictions to thirteen and develop a "Court Presidents Power Index". These jurisdictions include 12 jurisdictions covered by this special issue (CJEU, Czechia, ECtHR, France, Germany, Ireland, Italy, the Netherlands, Poland, Romania, Slovakia, and Slovenia) and Russia. ${ }^{171}$ By developing the "Court Presidents Power Index" we get an approximate picture of the strength of the court presidents in the studied jurisdictions. Moreover, our index allows us to identify several five types of court presidents (court president as a boss, court president as a judicial leader, court president as a manager, court president as a judicial diplomat, and court president as a primus inter pares) and revisit the claim that Western and Eastern Europe view the roles of court presidents differently.

\footnotetext{
${ }^{166}$ This was the case in Slovakia during the era of the Chief Justice Štefan Harabin (2009-2014). See Spáč, Šipulová \& Urbániková, supra note 77; and Kosař, supra note 9.

${ }^{167}$ This has been the case in Czechia since the late 1990s. See Kosař, supra note 11.

${ }^{168}$ Note that court presidents may build such loyalty by other means as well - for instance, by a selective use of administrative power or by not initiating the disciplinary motion against a judge who deserves it.

${ }^{169}$ See Part D.

${ }^{170}$ For potential avenues for future research see Part $\mathrm{E}$.

${ }^{171}$ For explanation, why we omitted Spain and Turkey and why we added Russia, see below.
} 


\section{Towards the "Court Presidents Power Index"}

In order to tentatively compare the strength of court presidents, we created a simple ordinal index of powers of court presidents ("Court Presidents Power Index"). We included every jurisdiction covered by this special issue about which we have a reasonable amount of information regarding the powers of court presidents, either from the contributions to this special issue or from additional sources. ${ }^{172}$ We also added Russia to the mix, because Russian court presidents wield more power than in any European jurisdiction covered by this special issue. ${ }^{173}$ This should allow us to see the strength of European court presidents in a better perspective.

As to the creation of the index itself, we take six out of seven ${ }^{174}$ powers of court presidents discussed in Part $\mathrm{B}^{175}$ and then we rate court presidents in each jurisdiction depending on the extent of their competences in each of these six areas. We use a three-level scale (extensive, intermediate and minimal power). Therefore for each power we rate whether the power wielded by the court presidents in each area is extensive, intermediate or minimal. ${ }^{176}$ If the power is extensive, a country is given 3 points, if the powers is intermediate, a country is given 2 points, and if the power is minimal, a country is allocated 1 point.

The decisive criterion for the rating is the consequentiality of the power given to the court president. Therefore, with regard to the power over judicial careers, court presidents who play a significant role in selecting, promoting and disciplining judges have extensive powers. Those court presidents who have the power to evaluate judges that can have repercussions for their potential career advancement or decide on the composition of another body that plays a key role in selecting judges have intermediate powers. In contrast, court presidents who can influence selection and promotion only indirectly, either through having a say in one of the many bodies involved in the selection of judges or through indirect influence over the promotion of judges, have minimal power. Similarly,

\footnotetext{
${ }^{172}$ That is why we omit Spain and Turkey, because we simply do not have sufficient, relevant and accessible information on Spanish and Turkish court presidents.

${ }^{173}$ See also Solomon 2012, supra note 41; Solomon, supra note 41, at 354; Schwartz \& Sykiainen, supra note 36 , in particular at 995-996, 1003, 1008-1009, 1012, 1018-1027 and 1031-1034; Popova, supra note 17.

${ }^{174}$ For pragmatic purposes, we leave aside the ancillary powers of court presidents as we do not have sufficient information about them and they are often incommensurable.

${ }^{175}$ We include both formal and informal powers of court presidents, as in many cases the informal powers are interlinked with the formal ones and may be even more consequential.

${ }^{176}$ This categorization is inspired by the table in Nuno Garoupa \& Tom Ginsburg, Guarding the Guardians: Judicial Councils and Judicial Independence, 57 AM. J. CoMP. L. 103, 122 (2009).
} 
extensive administrative power involves a direct influence on case assignment and panel composition, while the power to create work schedules would give court presidents intermediate power and the supervision of automatic case assignment counts as a minimal one. By repeating this exercise for each of the six powers of court presidents we get an approximate picture of their strength in the studied jurisdictions. The result of this rating can be seen in Table 1 below.

Table 1: Court Presidents Power Index: Typology of Powers

\begin{tabular}{|c|c|c|c|}
\hline Area & Extensive & Intermediate & Minimal \\
\hline Judicial Careers & $\begin{array}{c}\text { CZ, RU, SLO, SVK } \\
\text { (significant role in } \\
\text { selection, promotion, or } \\
\text { disciplining of judges) }\end{array}$ & $\begin{array}{l}\text { IRE, FR, RO, PL } \\
\text { (limited role in } \\
\text { selection or } \\
\text { promotion of } \\
\text { judges) }\end{array}$ & $\begin{array}{l}\text { CJEU, ECtHR (both } \\
\text { weak influence } \\
\text { over one of the } \\
\text { bodies involved in } \\
\text { election of judges), } \\
\text { GER (indirect } \\
\text { influence over } \\
\text { promotion of } \\
\text { judges), NL, IT }\end{array}$ \\
\hline Administrative & $\begin{array}{c}\text { FR (discretionary case } \\
\text { assignment), CJEU } \\
\text { (discretionary case } \\
\text { assignment), CZ, IT (panel } \\
\text { assignment + work } \\
\text { schedules), RU, PL, SLO }\end{array}$ & $\begin{array}{c}\text { SVK, IRE (work } \\
\text { schedules, } \\
\text { managing courts } \\
\text { including staff), NL } \\
\text { (case assignment), } \\
\text { ECtHR }\end{array}$ & $\begin{array}{l}\text { GER (shared } \\
\text { administrative } \\
\text { powers), RO } \\
\text { (supervising } \\
\text { random case } \\
\text { assignment), }\end{array}$ \\
\hline Financial & $\begin{array}{l}\text { RU (powers over bonuses, } \\
\text { kindergartens and flats) }\end{array}$ & $\begin{array}{l}\text { SLO (deciding on } \\
\text { education, } \\
\text { conferences), SVK, } \\
\text { FR (power over } \\
\text { salary bonuses) }\end{array}$ & $\begin{array}{c}\text { CZ, IT, NL, GER, PL, } \\
\text { IRE, RO, CJEU, } \\
\text { ECtHR } \\
\text { (power over court } \\
\text { budgets) }\end{array}$ \\
\hline Jurisprudential & $\begin{array}{l}\mathrm{CZ}, \mathrm{SVK}, \mathrm{PL}, \mathrm{RU}, \mathrm{CJEU} \\
\text { (opinion assignment + } \\
\text { additional resources) }\end{array}$ & $\mathrm{ECtHR}$ & $\begin{array}{c}\text { SLO, GER, IRE, FR, } \\
\text { IT, RO, NL }\end{array}$ \\
\hline Ambassadorial & $\begin{array}{c}\text { ECtHR, CJEU, RU } \\
\text { (represent judiciary, } \\
\text { communicate with the } \\
\text { executive/other organs) }\end{array}$ & $\begin{array}{c}\mathrm{PL}, \mathrm{CZ}, \mathrm{IRE}, \mathrm{SLO}, \\
\text { GER }\end{array}$ & $\begin{array}{l}\text { IT (opening of the } \\
\text { judicial year), NL } \\
\text { (speeches), FR, RO, } \\
\text { SVK }\end{array}$ \\
\hline
\end{tabular}




\begin{tabular}{|c|c|c|c|}
\hline Media & CJEU, ECtHR, CZ, SLO & RU & $\begin{array}{c}\text { SVK, GER, PL, IRE, } \\
\text { NL, FR, IT, RO }\end{array}$ \\
\hline Ancillary & Not studied & Not studied & Not studied \\
\hline
\end{tabular}

After rating each of the court presidents' powers in the respective jurisdictions, we added them up and created a ranking of the jurisdictions according to their court presidents' strengths.

Table 2: Court Presidents Power Index: Overall Strength of Court Presidents

\begin{tabular}{|c|c|}
\hline Country & Power Index \\
\hline Russia & 17 \\
\hline Czechia & 15 \\
\hline Slovenia & 14 \\
\hline CJEU & 14 \\
\hline $\begin{array}{c}\text { Poland } \\
\text { ECtovia }\end{array}$ & 10 \\
\hline France & $\mathbf{9}$ \\
\hline Ireland & $\mathbf{8}$ \\
\hline Italy & $\mathbf{7}$ \\
\hline $\begin{array}{c}\text { Romania } \\
\text { Germany }\end{array}$ & \\
\hline
\end{tabular}

We are aware of the fact that our Court Presidents Power Index is still tentative and should be approached with caution. This is so not only due to the scarce literature on court presidents and lack of empirical data, but also because the volatile nature of their powers changes over time. ${ }^{177}$ Not only do the powers change over time, but they also greatly

\footnotetext{
177 See e.g. the recent developments in Poland and Hungary. However, court presidents' powers have been subject to changes also in Czechia, Ireland, Slovakia, as well at the CJEU and the ECtHR.
} 
depend upon the respective court presidents' ability and willingness to use them. ${ }^{178}$ Therefore, our index should be viewed rather as a starting point for identifying broader trends and discovering various configurations of court presidents' powers that exist over Europe.

Despite the abovementioned limitations, Tables 1 and 2 reveal some interesting insights. Court presidents with the most extensive powers operate in Russia (17 points), followed by Czechia, Slovenia, and at the CJEU (14 to 15 points). At the other end of the continuum lie the Netherlands, Romania, Germany, Italy and Ireland (7 to 9 points). In the middle of the Table 2 we can find France, the ECtHR, Poland, and Slovakia (10 to 12 points). Russia lives up to the strongman archetype and Russian court presidents wield extensive powers in each area. However, the rest of Table 2 defies straightforward interpretation. Most importantly, we cannot simply conclude that Eastern court presidents are always stronger than their Western European counterparts, ${ }^{179}$ because the CJEU President is one of the most powerful and post-communist countries are actually represented not only at the top of Table 2, but also in the middle and even at the bottom of the ranking.

As mentioned above, the Court President Power Index allows us to analyze various configurations of court presidents' powers and identify types of court presidents in Europe. Two types of court presidents emerge clearly from our Index - a court president as primus inter pares and a court president as a boss. In the first type, the "first among equals", a court president has limited influence over the careers and financial well-being of individual judges, has limited influence on case assignment and usually shares her administrative powers with other bodies, and instead relies primarily on her leadership skills. Such court presidents also tend to be less visible in the media and do not play the major ambassadorial role. This type of court presidency has often been associated with the common law world. ${ }^{180}$

From our thirteen jurisdictions, Germany comes arguably closest to the primus inter pares type. ${ }^{181}$ Post-war German jurists have placed a strong emphasis on the independence of individual judges and set the strict limits on how court presidents may interact with rank and file judges. Cases are assigned strictly on random basis according to the criteria set in advance. $^{182}$ Even the general rules on the case assignment are not stipulated by court

\footnotetext{
${ }^{178}$ We address this issue in Part $D$ below.

${ }^{179}$ We address this issue in Part $\mathrm{D}$ below.

${ }^{180}$ Solomon, supra note 41; Lawrence David, The Face of an Institution: Beverley McLachlin's Reinvention of the Role of the Chief Justice of Canada, I-CONNECT, (December 7, 2017) http://www.iconnectblog.com/2017/12/david -on-chief-justice-mclachlin/.

${ }^{181}$ For a similar opinion, see also Solomon, supra note 41 , at 918 .

${ }^{182}$ See Seibert-Fohr, supra note 81 , at $481-483$.
} 
presidents, but by the Judicial Board (Präsidium) of each court. Though the court president is a member of this board, regular judges have a majority there. ${ }^{183}$ Moreover, regular judges can challenge the assignment of a particular case before administrative courts if they believe that the rules of case assignment were breached. ${ }^{184}$ The Judicial Service Courts have also forbidden court presidents from making any remarks that might influence the future performance of judges, even on matters on case management and efficiency. ${ }^{185}$ Similarly, any evaluation of judges must deal only with the outer order of judicial business, and not its core, or how the law is applied. ${ }^{186}$ The only area are where court presidents have arguably retained their informal powers is promotion as several commentators suggest that German judges who seek promotion may be tempted to adjust their decisionmaking according to the views of their court presidents. ${ }^{187}$

Similarly, the powers of Dutch court presidents have been diluted over time. They no longer act alone, but chair the three-member Management Board, which decides on the division of the court into chambers, the allocation of cases, and the day-to-day management, organization and operations of the court. ${ }^{188}$ Dutch court presidents thus have rather limited influence over the lives and careers of individual judges.

Interestingly, Romanian court presidents also seem to be rather weak. ${ }^{189}$ They serve a relatively short three-year mandate (once renewable), have no influence on case assignment as they merely supervise the system of random case assignment, and have mainly court administration competencies. ${ }^{190}$ They have limited influence over the career of rank and file judges, as their only real power is having a say in periodical evaluation of judges which may affect promotion prospects of individual judges. Moreover, their powers are curtailed by the existence of a Ruling Board, which has most decision-making

\footnotetext{
${ }^{183}$ See Art. 21a Gerichtsverfassungsgesetz (German Constitutional Law on Courts).

${ }^{184}$ See Judgment of the German Federal Administrative Court of 28 November 1975 (BVerGE 50, $11=$ NJW 1976, 1224).

185 Johannes Riedel, Recruitment, Professional Evaluation and Career of Judges and Prosecutors in Germany, In, Recruitment, Professional Evaluation and Career of Judges and Prosecutors in Europe (Giuseppe Di Federico ed., IRSIG-CNR 2005) 69-126, at 98-107.

${ }^{186}$ Anja Seibert-Fohr, Constitutional Guarantees of Judicial Independence in Germany, in RECENT TRENDS IN GERMAN AND EuRopean CONSTITUtIONAL LAW 267, at 271 (Eibe H. Riedel \& Rüdiger Wolfrum eds., 2006).

${ }^{187}$ Levitt, supra note 82, at 197-198; and Seibert-Fohr, supra note 81, at 502.

${ }^{188}$ Mak, supra note 89.

${ }^{189}$ See Gutan, supra note 67; and lancu, supra note 67, at 594-596.

${ }^{190}$ See Gutan, supra note 67 . Note that the mandate of court presidents shall be prolonged to four years.
} 
powers. ${ }^{191}$ Thus, court presidents are designed more as "administrators of the courts rather than actual leaders". ${ }^{192}$

Italy and Ireland also seem to belong to this type, even though their court presidents are a bit stronger than their Romanian, German and Dutch counterparts. Italian court presidents, beyond standard administrative tasks, participate in the process of evaluating judges and have retained some influence over allocation of cases. ${ }^{193}$ Irish court presidents also play an important role in disposal and allocation of cases and setting the policy, but they have only limited powers vis-à-vis their colleagues on the bench. This internal independence of rank-and-file judges vis-à-vis court presidents is further buttressed by "a very strong cultural conception of individual judicial independence, which has traditionally overshadowed corporate or collective judicial independence", ${ }^{194}$ and the fact that Irish judges are not socialized within the judiciary and instead join the bench as already successful leading figures of the Bar and other legal professions. However, Irish court presidents have a say in selection of new judges and their last-minute fightback in the Irish parliament against the 2018 judicial reform that could limit their role in this area shows their strength. $^{195}$

In the second type, the "boss", a court president decides on case assignment, evaluates judges of her court and has significant influence over their promotion, decides when judges should be disciplined, influences well-being of judges through various discretionary perks such as vacation packages, help in obtaining apartments or getting children into schools or nurseries, operates as a power broker with local or national political leaders, and is usually active in the media and as ambassador of a given court. This model exists in Russia ${ }^{196}$ and many post-Soviet states. ${ }^{197}$ As Solomon has pointed out, "[t]he chair of the court in Russia is and remains a 'boss', a super authority who manages his domain and

\footnotetext{
${ }^{191}$ See Gutan, supra note 67.

${ }^{192}$ See Gutan, supra note 67.

${ }^{193}$ Benvenuti \& Paris, supra note 89.

${ }^{194}$ O’Brien, supra note 70.

195 See Michael O'Regan, Judicial appointments Bill passes in Dáil and now goes to Seanad, THE IRISH TIMES (May 31, 2018), https://www.irishtimes.com/news/politics/oireachtas/judicial-appointments-bill-passes-in-d\%C3\%A1iland-now-goes-to-seanad-1.3515540?mode=amp.

196 See Solomon 2010, above note 41; Solomon 2012, supra note 41; and Schwartz \& Sykiainen, supra note 36, in particular at 995-996, 1003, 1008-1009, 1012, 1018-1027 and 1031-1034; and Popova, supra note 41.

197 See Müller, supra note 41, at 965 (on Ukraine, Moldova, Armenia, Azaerbaijan and Belarus); Popova, supra note 41 (on Ukraine); and Alexei Trochev, Patronal politics, judicial networks and collective judicial autonomy in post-Soviet Ukraine, 39 INTERNATIONAL Political SCIENCE REVIEW 662 (2018), at 670-674.
} 
represents the court in the outside world, including in informal dealings with local authorities, whose support still matters for the well-being of the court" ${ }^{198}$

These two types can also be seen as two sides of the continuum. Most European judiciaries covered by this study lie somewhere in between these two poles. This is the case of Czechia, Slovenia, the CJEU, Poland, Slovakia, the ECtHR, and France. Within this group we can trace three configurations of powers that result in the following three tentative types the judicial leader type (Czechia, Slovenia, the CJEU), the judicial diplomat type (the ECtHR) and the manager type (Poland, Slovakia and France).

The court president as a judicial leader is not as strong as Russian court presidents, because he is not a boss who may to a great extent affect well-being of rank-and-file judges. However, she still has not only broad ambassadorial and media power, but also has a major say in case assignment and panel composition (administrative power). In addition, she usually wields significant jurisprudential power through setting the rules of the debate, opinion assignment and shaping the law (the CJEU and Czechia) and often has major say over judicial careers, either in selecting and disciplining (Czechia) or in promoting judges (Slovenia).

The court president as a manager combines weak ambassadorial, media and financial powers with at least intermediate power over allocation of cases, important say in careers of individual judges and strong jurisprudential power. Therefore, managers tend to be strong regarding the internal powers vis-à-vis their colleagues on their court, but are less active in external relations. The typical examples of this type are Poland and Slovakia. France comes close too, but French court presidents seem to have less jurisprudential power than their Polish and Slovak colleagues.

In contrast, the court president as a judicial diplomat has weak power over the career of her colleagues and their well-being and little influence on allocation of cases, but he wields significant power over the staff of her court and has extensive ambassadorial and media power as well as intermediate jurisprudential power. The limited financial power and power over judicial careers distinguishes this type from the judicial leader type, the boss type as well as from the managerial type. However, her ambassadorial, media and jurisprudential power sets judicial diplomat apart from the primus inter pares type. Out of our 13 jurisdictions, only the ECtHR President fits this type. Her power lies primarily in her "diplomatic missions" to the domestic courts and parliaments. her broad media activity, her formal authority to wield power over the Registrar and the staff of the ECtHR, the fact that she sits automatically at the Grand Chamber formations, in having informal influence in choosing the cases to be identified as pilot judgments, and in acting as a power broker

${ }^{198}$ Ibid., at 354. See also Solomon, supra note 41. 
between the different Sections of the ECtHR with regard to referrals of cases to the Grand Chamber. $^{199}$

II. Weak Court Presidents in Western Europe vs. Strong Court Presidents in Eastern Europe: A Seductive but False Simplification

In the Court Presidents Power Index we categorized court presidents in 13 European jurisdictions according to how strong they are and identified five types of court presidents. In this subsection we build on this categorization and revisit the claim that there is a clear West/East division regarding the roles of court presidents in Europe. In order to do so, we analyze to what extent this position corresponds to our findings regarding each component of court presidents' power as well as regarding the overall strength of court presidents.

The standard account in the literature suggests that there is a huge divide between the powers of court presidents in Eastern Europe on the one hand and court presidents in Western Europe on the other. ${ }^{200}$ This claim also implicitly conveys the message that the power of court presidents in each part of Europe is relatively uniform. Regarding Eastern Europe, Kosař has argued that court presidents are invisible masters of the CEE judiciaries irrespective of the model of court administration in place, ${ }^{201}$ even though their powers may in some countries be rather fragile. ${ }^{202}$ This is so because "[t]hey are the key principals of individual judges [..., ] have the best overview of what is going on within the judiciary [..., and $t$ ]hey can use the most important stick in the civil law judiciaries (disciplinary motion) and have a major say in the most important carrot (promotion of judges)" ${ }^{203}$ In other words, information asymmetry and political capital further buttress their formal and informal powers. Other authors writing on courts in the CEE concur. ${ }^{204}$

In contrast, the strength and importance of court presidents in CEE which make up an important part of the discourse on the CEE judiciaries "appear alien to jurists in many

\footnotetext{
${ }^{199}$ Çalı \& Cunningham, supra note 29.

${ }^{200}$ See supra note 60.

${ }^{201}$ Kosař, supra note 9, at 390-398.

${ }^{202}$ Kosař, supra note 11 , at $110-114$.

${ }^{203}$ Kosař, supra note 9 , at 390.

204 See e.g. Bobek, supra note 35, at 253-254 (on Czechia); or Piana, supra note 37, at 43-44 (on Czechia, Hungary, Poland, Bulgaria and Romania); Solomon, supra note 41, at 354 (on Russia); Müller, supra note 41, at 965 (Ukraine, Moldova, Armenia, Azaerbaijan and Belarus); Schwartz \& Sykiainen, supra note 36, in particular at 995-996, 1003, 1008-1009, 1012, 1018-1027 and 1031-1034 (on Russia); and, on Slovakia, Alexander Bröstl, At the Crossroads on the Way to an Independent Slovak Judiciary, In SYSTEMS OF JUSTICE IN TRANSITION: CENTRAL EUROPEAN EXPERIENCES SINCE 1989 (Jiří Přibáň, Pauline Roberts \& James Young eds., 2003) at 141, 143.
} 
Western Member States". ${ }^{205}$ According to this account, even in countries such as Germany in which court presidents wielded historically broad powers, they have undergone significant transformation and lost most of their powers. ${ }^{206}$ Some commentators even suggested that, as a result of these changes, German court presidents "have lost the capacity to give instructions to rank and file judges on matters related to particular cases ... and ... come closer to the common law model of primus inter pares than the dominant figure (boss) normally associated with court heads in the civil law world". ${ }^{207}$ Other established democracies in Western Europe likewise reduced the role of hierarchical oversight within their judiciaries over the past 50 years and changed the role of court presidents profoundly. ${ }^{208}$ The only area where Western European court presidents, according to this account, seem to have retained some of their former power over rank and file judges is the promotion of judges. ${ }^{209}$

In other words, the existing literature suggests that court presidents are strong players in Eastern Europe, whereas in Western Europe they have become rather representative figures. However, both our Court Presidents Power Index and the several contributions to this special issue challenge this view. Most importantly, Romanian court presidents do not fit into this simple dichotomy as they rank among the weakest in our set of 13 jurisdictions. They operate as "first among equals", similarly to court presidents in Germany, and the Netherlands. They are weaker than their counterparts in Italy, Ireland and France. Conversely, French court presidents have still retained significant powers as they not only have major influence on allocation of cases, but also have their say in selection and promotion of judges. Moreover, if we add the CJEU's President into the picture, the power of court presidents in many CEE countries look relatively meager. In fact, the CJEU's President ranks among the strongest in Europe and is a true judicial leader. He not only has extensive jurisprudential, ambassadorial and media power, but also enjoys significant discretion in case assignment and through determining the composition of the Article 255 Panel also influences selection of new CJEU's judges. If we leave Russia aside, only Czech court presidents are arguably stronger.

\footnotetext{
${ }^{205}$ Wallerman, supra note 60 , at 676-677.

${ }^{206}$ See Riedel, supra note 185, at 69, 98-107; Seibert-Fohr, supra note 186, at 267, 271; Solomon, supra note 41; Levitt, supra note 82, at 197-198; and Seibert-Fohr, supra note 81, at 502 (these two authors suggest that judges who seek promotion may be tempted to adjust their decision-making according to the views of their court presidents).

${ }^{207}$ Solomon, supra note 41 , at 918.

${ }^{208}$ Anja Seibert-Fohr, Judicial Independence - The Normativity of an Evolving Transnational Principle, In SeibertFohr, supra note 17 , at $1279,1329$.

${ }^{209}$ See Levitt, supra note 82, at 197-198 (on Germany); and Seibert-Fohr, supra note 81, at 502 (on Germany); Garapon \& Epineuse, supra note 78, at 285-286 (on France).
} 
In fact, when we look at our Court Presidents Power Index without any bias, we can see that while court presidents in some CEE countries are on the upper side of the continuum, it is difficult to draw the easy line along the West/East axis. Importantly, Romanian case study shows that strong court presidents are not an inherent feature of all CEE judiciaries and that it is possible to reduce the power court presidents in the CEE context. What emerges clearly is a more complex picture: even though Western European court presidents are in general weaker than their Eastern European counterparts (with exception of Romania), powers of court presidents diverge within Western Europe as well as within Eastern Europe. What is more, powers of court presidents differ also between the CJEU and the ECtHR. Put differently, there is no consensus regarding the role of court presidents in Europe, neither on the domestic nor on the transnational level. To make things even more complicated, powers of court presidents do not automatically translate into their influence, which is dependent on various contingent circumstances. We will analyze these contingent circumstances in the next Part.

\section{Powers Do Not Automatically Translate into Influence: Contingent Circumstances Can Make the Difference}

In the previous two Parts we categorized powers of court presidents, developed the Court Presidents Power Index and identified the five types of court presidents. In this Part we will problematize this index and show that powers are not necessarily the only factor that determines the influence of court presidents. We argue that there are other determinants that may restrain or bolster the utilization of powers of court presidents. We refer to these additional determinants as the contingent circumstances of court presidents' power. These contingent circumstances include the length of term of court presidents, the existence of information asymmetry, the structure of the judiciary, the existence of competing bodies, the role of individuals, the proximity of court presidents to political leaders, and the influence of the legal profession, legal culture, and political environment.

The existence of these contingent circumstances does not mean that the Court Presidents Power Index is to a large extent irrelevant (and we certainly do not want to convey this message), and that it all depends on, for instance, legal culture or who holds this office. To the contrary, this index still matters, because the interaction between powers of court presidents and contingent circumstances is mutual. For instance, the scope of powers of court presidents also shapes legal culture and determines what type of judges seek to hold this office. It is thus important to keep this interaction in mind when analyzing contingent circumstances in individual jurisdictions.

First, the longer the term of court presidents, the more power they arguably wield. The long term of office allows the court president to leave a greater imprint on the law, to master all her competences, to develop a deeper knowledge of judges of her court, to expand her networks, to foster her relationship with the media, and to increase her ambassadorial activities. Especially if the term of a court president significantly surpasses 
the term of office of the members of the legislature and the executive, she may be particularly valued for her institutional memory and politicians may be forced to rely on her knowledge in personal decisions within the judiciary. Not surprisingly, the governments that intend to curtail the role of court presidents try to limit their term in office. This can be done formally as well as informally. For instance, the Czech Parliament introduced a non-renewable term ${ }^{210}$ for court presidents in 2008 in order to reduce their influence within the Czech judiciary. ${ }^{211}$

A more intriguing technique is to select court presidents from among judges whose age is close to a compulsory retirement age. ${ }^{212}$ In contrast the most blatant technique is dismissal of "unwanted" court presidents. ${ }^{213}$ Finally, sometimes the reduction of the length of a court president's term is just an unintended consequence of a judicial reform aimed primarily at something else. This might be the case of the ECtHR, where the introduction of a non-renewable nine-year term for Strasbourg judges in 2010 also shortened the potential length of term of the ECtHR's President. Put differently, no one can become such a towering figure like Rolv Ryssdal, who presided over the Strasbourg Court for 13 years (1985-1998), or Luzius Wildhaber, who led the ECtHR from 1998 to 2007.. ${ }^{214}$ This institutional change, brought about by Protocol No. 14, thus arguably made the ECtHR's presidents de facto weaker than their counterparts at the CJEU, where a renewable term for judges is still allowed. ${ }^{215}$

The second factor, information asymmetry, is closely connected with this one. Wide information asymmetry can significantly boost court presidents' powers, as they are much closer to what is going on in the judiciary, and other stakeholders may be forced, however reluctantly, to rely on their knowledge in making the policy as well as personal decisions on the judiciary. ${ }^{216}$ On the other hand, enhanced transparency may limit court presidents' discretion in the exercise of their powers, as it increases public control and may even result in holding court presidents to account for their actions. ${ }^{217}$

\footnotetext{
${ }^{210}$ The term ranges from seven to ten years, depending on the tier of the Czech judiciary.

${ }^{211}$ See e. g. Kosař, supra note 11; and Blisa, Papoušková \& Urbániková, supra note 89.

${ }^{212}$ This is a common practice (at least for apex courts) in Japan; see David S. Law, The Anatomy of a Conservative Court: Judicial Review in Japan, 87 TEXAS LAW REVIEW 1545 (2009).

${ }^{213}$ See notes $1-17$

214 In fact, none of Wildhaber's successors (Jean-Paul Costa, Nicholas Bratza, Dean Spielmann, and Guido Raimundi) presided over the ECtHR for more than 5 years (and usually much less).

${ }^{215}$ Note that Gil Carlos Rodríguez Iglesias held the office of the CJEU President for 9 years (1994-2003), Vassilios Skouris for 13 years (2003-2015), and Koen Lenaerts has been the CJEU's President since 2015.

${ }^{216}$ This has happened in Czechia. See Kosař, supra note 11; and Blisa, Papoušková \& Urbániková, supra note 89.

${ }^{217}$ This seems to be the case in Slovakia. See Spáč, Šipulová \& Urbániková, supra note 77.
} 
The next two factors concern institutional design issues. The third factor is the structure of the judiciary. One may argue that the strictly hierarchical judiciary with few appellate and apex court presidents makes them stronger than the flat structure with multiple special courts. For instance, the Slovak judiciary that resembles a simple pyramidal shape of three court tiers (district courts, regional courts and one Supreme Court) ${ }^{218}$ with no special courts $^{219}$ increases the role of court presidents. Similarly, the Czech judicial system also follows a hierarchical pattern, but it consists of four tiers (district courts, regional courts, high courts, the Supreme Court) and features a specialized apex court for administrative law matters, the Supreme Administrative Court. ${ }^{220}$ The structure of the Slovenian judicial system is also relatively hierarchical, but it arguably dilutes the power of court presidents even more than in the Czech Republic, as Slovenia has not only a four-tiered judicial system and the separate Administrative Court, but also specialized labor and social courts and the Court of Audit. ${ }^{221}$ But that is nothing in contrast to judiciaries in the established democracies covered by this special issue. Ireland's judiciary consists of five tiers of general courts and a plethora of special tribunals. France is well-known for its convoluted judicial system and the two-headed judiciary, in which criminal and civil judges (magistrates) follow a different path than the administrative tribunals headed by the Conseil d'État. ${ }^{222}$ In Germany, only at the federal level are there as many as five separate judiciaries with their own apex court (Bundesgerichtshof, Bundesverwaltungsgericht, Bundesarbeitsgericht, Bundesfinanzhof, Bundessozialgericht). ${ }^{223}$ In addition, Germany also created a federal patents court, the Bundespatentgericht, and special disciplinary courts. ${ }^{224}$ Such a flat structure inevitably reduced the powers of court presidents who are just one among many.

The fourth factor that emerges from this special issue clearly is the existence of other competing JSG bodies such as judicial councils or judicial appointment commissions. It is no surprise that (leaving aside Russia) court presidents wield the strongest power in Czechia,

\footnotetext{
${ }^{218}$ See Spáč, Šipulová \& Urbániková, supra note 77; and Kosař, supra note 9, at 254-264.

${ }^{219}$ Note that there is the Specialized Criminal Court, established in 2009, but it operates in a very similar way as the general criminal courts and its judgments can be appealed to the Slovak Supreme Court.

${ }^{220}$ See Blisa, Papoušková \& Urbániková, supra note 89; and Kosař, supra note 9, at 181-187.

${ }^{221}$ See Avbelj, supra note 76.

222 See Vauchez, supra note 78; Garapon \& Epineuse, supra note 78; SERGE GUINCHARD, GABRIEL MONTAGNIER, ANDRÉ

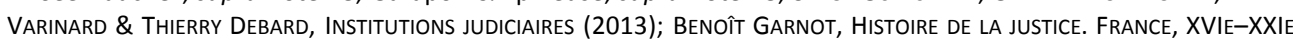
SIÉCLE (2009); and BRUno LATOUR, THE MAKIng of LAW: AN ETHNOGRAPHy Of THE CONSEIL D’ETAT (2010).

223 See Fabian Wittreck, Die Verwaltung der Dritten Gewalt (2006); Werner Heun, The Constitution of Germany: A CONTEXTUAL ANALYSIS (2011), at 166-167; Wittreck, supra note 92.

${ }^{224}$ See ibid.
} 
where no such competing body exists. ${ }^{225}$ In contrast, in all five countries on the other side of the Court Presidents Power Index (Germany, Ireland, Italy, the Netherlands, and Romania) $)^{226}$ court presidents have to compete for power in an increasingly crowded space. In Italy and Romania court presidents face a strong judicial council, which has over the years taken away some of their powers and weakened hierarchical supervision more generally. $^{227}$ In the Netherlands court presidents have to interact with the three-member Management Board established at every court of first instance and court of appeal as well as with the nation-wide Council for the Judiciary. ${ }^{228}$ In Ireland court presidents have to guard their powers against the Court Service, the Judicial Appointments Advisory Board (from 2018 to be replaced by the Judicial Appointments Commission), and soon perhaps also against a judicial council. ${ }^{229}$ The German contribution then shows that the powers of court presidents can be diluted even in the absence of a nation-wide JSG body such as a judicial council, a courts service, or a judicial appointments board. While the influence of court presidents varies from one Land to another, each of them faces a plethora of JSG bodies on the court level (Presidia) as well as on the Land level (Councils of Judges, Councils of Judicial Appointment, Service Courts, and Committees for Selection of Judges). ${ }^{230}$

Apart from institutional factors, we should not forget that individuals matter too. While this article is primarily about the institution of the court president, individuals holding this office may significantly affect the authority and legitimacy of this institution, which in turn determines real influence of court presidents in a given jurisdiction. ${ }^{231}$ This is particularly true for the Chief Justices. More specifically, an individual Chief Justice may transfer her authority and legitimacy to an institution of the Chief Justice. The typical example is the President of the CJEU Koen Lenaerts, who has been a prolific scholar and has been considered as one of the intellectual leaders in the field of EU law, is a skillful judicial

\footnotetext{
${ }^{225}$ See Blisa, Papoušková \& Urbániková, supra note 89.

${ }^{226}$ See Part C.I.

${ }^{227}$ See Benvenuti \& Paris, supra note 89; CARlo Guarnieri \& PATRIZIA Pederzoli, The Power of Judges: A Comparative STUdY OF COURTS AND DEMOCRACY (2002), at 54-55; or Carlo Guarnieri, Judicial Independence in Europe: Threat or Resource for Democracy?, 49 REPRESENTATION 347 (2013), at 348 (all on Italy); and Gutan, supra note 67; and lancu, supra note 67, at 594-596 (both on Romania).

${ }^{228}$ Mak, supra note 89.

${ }^{229}$ O'Brien, supra note 70. However, the proposed Judicial Council will be chaired by the Chief Justice and it is unlikely (at least in the short term) that the fairly consensual approach that has been taken by successive Chief Justices in relation to the Courts Service would not also be carried through into the operation of the Judicial Council.

${ }^{230}$ Wittreck, supra note 92.

${ }^{231}$ We are grateful for this insight to Julio Ríos-Figueroa.
} 
diplomat and is well-connected not only within the EU institutions but also within legal academia, speaks several other languages beyond French and English, and is well-regarded by legal community both in Europe and on the other side of the Atlantic. ${ }^{232}$ Beyond Europe the Canadian Chief Justice Beverley McLachlin ${ }^{233}$ and the Pakistani Chief Justice Iftikhar Chaudhry $^{234}$ have arguably achieved the same status. Such Chief Justices can use their gravitas to increase their visibility and influence within their legal systems. The downside is that once these towering figures step down, some of their individual authority and legitimacy might go away too and the new Chief Justice might be much less influential. ${ }^{235}$ At the same time, we must not forget that individual Chief Justice may also erode the authority and legitimacy of the institution of the Chief Justice. Here the Slovak Chief Justice Štefan Harabin ${ }^{236}$ and the Chief Justice of the Supreme Court of the United States Roger Taney $^{237}$ come to mind. The Slovak contribution to this special issue also shows how difficult it is to restore the lost reputation of the office of the Chief Justice. ${ }^{238}$

This brings us to the sixth factor, the proximity of court presidents to political leaders. Court presidents who belong to the social milieu of the political elite have better access to key stakeholders and may use this lobbying capacity to resist, initiate, adopt and implement judicial (and legal reforms) and counter-reforms. In several countries judges can be temporarily assigned to the Ministry of Justice and other state organs, ${ }^{239}$ which allows them to use these contacts later on once they become court presidents. Many CEE countries witnessed the phenomenon of "superjudges". ${ }^{240}$ By a "superjudge" we mean a professional judge who at some point of her career became the minister or vice-minister and then returned to the judiciary. The sequence is important. A "superjudge" had been a judge before she joined the executive and then returned to the judiciary, empowered by all the knowledge and contacts she made within the executive branch. As shown above,

\footnotetext{
${ }^{232}$ Wittreck, supra note 92.

${ }^{233}$ See I-CONnect Symposium on the Legacy of Beverley McLachlin, Chief Justice of Canada; and in particular David, supra note 142 .

${ }^{234}$ See supra notes 22 and 244.

${ }^{235}$ This makes the choice of their successors extremely difficult.

${ }^{236}$ See Kosař, supra note 9, at 320-321, 327-329; and Spáč, Šipulová \& Urbániková, supra note 77.

${ }^{237}$ Chief Justice Roger Taney delivered the infamous majority opinion in Dred Scott v. Sandford (60 U.S. (19 How.) 393 (1857)), ruling that African Americans could not be considered citizens and that Congress could not prohibit slavery in the territories of the United States. For further details, see DON E. FEHRENBACHER, THE DRED SCOTT CASE: ITS SIGNIFICANCE IN AMERICAN LAW AND POLITICS (2001).

${ }^{238}$ See Spáč, Šipulová \& Urbániková, supra note 77.

${ }^{239}$ This is a standard practice in Austria, Germany and France (for Conseillers d'État).

${ }^{240}$ For further details, see Kosař, supra note 9, at 173-176, 248-250.
} 
such "travelling among branches" is not specific to CEE. However, for historical reasons this practice is particularly troubling in post-communist judicial systems. ${ }^{241}$ In semiauthoritarian regimes proximity to political leaders plays even greater role, since being integrated in the ruling patronal network or the ruling family brings about more perks and might be crucial for the long-term survival of court presidents. ${ }^{242}$

The final set of factors involves a broader legal and political background. The varying influence of the legal profession is the seventh factor. Especially in common law countries, where the connection between the bench and the Bar is particularly strong, the legal profession may empower as well as constrain court presidents. Typically, the legal profession may play a gate-keeping role and its structure may affect judicial selection. ${ }^{243} \mathrm{At}$ the same time, lawyers may mobilize the people against political attack on court presidents. We saw this most clearly in Pakistan after General Pervez Musharaff suspended Chief Justice Iftikhar Chaudhry. ${ }^{244}$ However, even in Poland some members of the legal profession have come out strongly against the Law and Justice Party's attempt to get rid of the Polish Supreme Court President, Małgorzata Gersdorf. ${ }^{245}$

The eighth factor is legal culture, which is even more deeply embedded than the role of the legal profession. Most importantly, despite the growing convergence between the "career" and "recognition" judiciaries, ${ }^{246}$ they still produce different types of identity within the judiciary. Distinctive features of both models are well-known. ${ }^{247}$ Here it suffices to say that career judges who enter the judiciary at a relatively young age at the bottom of the judicial hierarchy and become fully socialized within the judicial ranks are more prone to deferring to court presidents than judges in recognition judiciaries who join the bench no sooner than in the middle of their careers with life wisdom and experience gained outside the judiciary. ${ }^{248}$ Put differently, career judiciaries tend to be more hierarchical and tend to deny individual identity to judges, whereas the recognition judiciaries largely

\footnotetext{
${ }^{241}$ See ibid.

${ }^{242}$ See Trochev, supra note 197 , at 670-674.

${ }^{243}$ Lizzie Barmes \& Kate Malleson, The Legal Profession as Gatekeeper to the Judiciary: Design Faults in Measures to Enhance Diversity, 74 THE MODERn LAW REVIEW 245 (2011).

${ }^{244}$ Ghias, supra note 22.

${ }^{245}$ See note 5 above.

246 See Nicholas Georgakopoulos, Independence in the Career and Recognition Judiciary, $7 \mathrm{U}$. $\mathrm{CHI} . \mathrm{L}$. SCH. ROUNDTABLE 205 (2000); or Nuno Garoupa \& Tom Ginsburg, Hybrid Judicial Career Structures: Reputation Versus Legal Tradition, 3 JOURNAL OF LEGAL ANALYSIS 411 (2011).

${ }^{247}$ See supra notes 52 and 146.

${ }^{248}$ Kosař, supra note 9 , at 113-120.
} 
revolve around the notion of individuality. ${ }^{249}$ This explains that court presidents are not considered "superiors" of other judges in recognition models. In contrast, hierarchical ${ }^{250}$ judiciaries tend to leave more room for maneuver to court presidents.

Finally, the political culture makes a difference too. For instance, while politicians in Western Europe do not consider the dismissal of a court president as a legitimate strategy, their counterparts in Eastern Europe resort to this measure quite often. ${ }^{251}$ At the same time, court presidents in Western Europe who commit problematic acts tend to resign voluntarily amid the pressure from their peers and political culture. In contrast, court presidents in Eastern Europe in similar situation tend to fight until the bitter end. ${ }^{252}$ Finally, political environment which is hostile to judges, such as the recent situation in Poland, ${ }^{253}$ inevitably puts court presidents under heavy pressure, because they are viewed as representatives of the judiciary and thus they easily end up in a direct conflict with political leaders.

To sum up, the fact that court presidents have the majority of the powers discussed in Part $B$ does not necessarily mean that they can and will use all of these powers in practice and that they can and will stretch them to their limits. Put differently, powers in the meaning of faculty do not necessarily translate into power in the meaning of influence. This depends on several contingent circumstances that are difficult to quantify. This does not undermine the Court Presidents Power Index, but merely suggests that a complete account of how court presidents maintain their power can be adequately presented only with respect to a particular jurisdiction and only with deep knowledge of the functioning of the given judiciary, both in the de iure and de facto dimensions, and accounting for the political and historical background.

\footnotetext{
${ }^{249}$ Sophie Boyron, The Independence of the Judiciary: A Question of Identity, In INDEPENDENCE, ACCOUNTABILITY, AND THE JUDICIARY (Guy Canivet, Mads Andenas \& Duncan Fairgrieve eds., 2006), at 77, 77-78. See also Mirjan Damaška's famous distinction between the hierarchical ideal of the officialdom and the coordinate ideal of

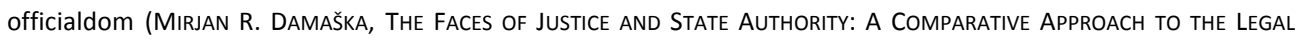
PROCESS (1986) at 16-46 and 181-239.

${ }^{250}$ We are, of course, aware that there are other factors than the career/recognition distinction that may affext the strength of hierarchical principle.

${ }^{251}$ See notes 1-17.

252 See Spáč, Šipulová \& Urbániková, supra note 77 (regarding the former Chief Justice of the Slovak Republic Štefan Harabin).

${ }^{253}$ See Śledzińska-Simon 2018, supra note 4.
} 


\section{E. Conclusion}

This article showed the multiple roles court presidents play in domestic as well as transnational judiciaries. They may wield broad powers, ranging from power over judicial careers of their colleagues on the bench, case assignment, and jurisprudential power, to financial power, ambassadorial and media power. We also analyzed 13 European jurisdictions and ranked their court presidents according the strength of their power. This resulted in the Court Presidents Power Index, first of its kind, which showed various configurations of court presidents' powers and allowed us to identify five types of court presidents: court president as a boss, court president as a judicial leader, court president as a manager, court president as a judicial diplomat, and court president as a primus inter pares. Our index also forces us to rethink the traditional view that Eastern European court presidents are much stronger than their counterparts in Western Europe, since the West/East division regarding the powers of court presidents is not as clear as presented in the existing literature.

We also identified several promising avenues for further research. First, we need to take stock of other jurisdictions and work more on the types of court presidents, both in Europe and beyond. Second, further research should distinguish between different tiers of the judiciary in which court presidents operate. We should probably single out Chief Justices, as they have unique position. It is also clear that the powers of presidents of appellate courts may differ from the powers of presidents of lower courts. To add to complexity, apex court presidents do not necessarily have more influence than other court presidents. For instance, in Czechia regional court presidents arguably wield more power than the President of the Supreme Court and the President of the Supreme Administrative Court. ${ }^{254}$ We need to understand how this has happened and under what circumstances such phenomenon persists.

The contributions to this special issue also showed that court presidents play a major role in judicial politics and thus it is particularly interesting to explore how they react to the introduction of a new judicial self-governance body. Under what circumstances do they resist such reform? If the resistance does not succeed, do they embrace the new JSG body or do they try to weaken, contest or even capture it? Under what circumstances they may succeed and what techniques they use to achieve that end? We may also inquire how court presidents interact with other bodies involved in judicial governance and with politicians. In fact, political contestation between court presidents and political leaders has been quite common recently. ${ }^{255}$ The ongoing conflict between the Polish Supreme Court President, Małgorzata Gersdorf, and Law and Justice Government has even become one of the key issues in the debate about the future of the European Union.

\footnotetext{
${ }^{254}$ See Blisa, Papoušková \& Urbániková, supra note 89.

${ }^{255}$ See notes $1-17$.
} 
This brings us to the next important question: Are there some powers of court presidents that are more prone to political attack? We may also rephrase this question and ask whether a particular type of court presidents is more susceptible to political backlash. In order to answer these two questions, we first need to understand why politicians want to get rid of 'problematic' court presidents. Do they want to improve efficiency and leadership, change the perception of the given court by the public or incrementally shift the course of law? Or they just need to have sufficient and reliable information what is going on in the judiciary? Or do they rather intend to silence or side-line their critics, suppress judicial dissent, pave the way for bringing in more loyal personnel, and ensure that the courts will yield judgments favoring the ruling political elite? In the worst case scenario, do politicians want to use court presidents as transmission belts ${ }^{256}$ to openly advance their agenda? This approach has an important advantage for the ruthless political leaders - by "outsourcing" judicial interferences to court presidents, political leaders can easily protect themselves from criticism for direct meddling with the judiciary, because using court presidents to advance their agenda is more opaque than purging the judicial corps or using coercion. ${ }^{257}$

The attempts of taming 'recalcitrant' court presidents in Hungary, Poland, Slovakia and Ukraine ${ }^{258}$ also bring to the fore what can be done to prevent this from happening or at least to minimize the incentives to meddle with selection and dismissal court presidents. One policy implication comes to mind immediately - to go normative and reduce the powers of court presidents, especially in post-communist countries. To be sure, it is a simple and seductive solution. However, is it the right path? If we take away some power from court presidents, this power does not disappear. It will be transferred to someone else. Therefore, we would have to think twice whom should we transfer this power to and whether such transferal would not make things even worse. Moreover, we also have a potential counterfactual, since Romania's judiciary does not fare well, ${ }^{259}$ despite having relatively weak court presidents. ${ }^{260}$

There are simply many pressing questions and few answers. In order to answer these questions, we need to broaden our horizons and analyze judicial self-governance from a

\footnotetext{
${ }^{256}$ On the transmission belt metaphor, see note 123.

${ }^{257}$ Alexei Trochev, Judicial Clientelism in Kazakhstan, (unpublished manuscript, on file with authors). See also notes $18-19$

${ }^{258}$ See notes 1-17.

${ }^{259}$ See Gutan, supra note 67; and lancu, supra note 67, at 594-596.

${ }^{260}$ See ibid; and Part C.
} 
more holistic view and look beyond traditional suspects such as judicial councils and judicial appointment committees. Only then we may come closer to understanding the place of court presidents in the puzzle of judicial governance. 
